\title{
GROUND-WATER DATA COLLECTED AT THE NEVADA TEST SITE AND VICINITY, NYE COUNTY, NEVADA, WATER YEARS 1988-89
}

By David B. Wood

U.S. GEOLOGICAL SURVEY

Open-File Report 92-130

Prepared in cooperation with the

NEVADA FIELD OFFICE,

U.S. DEPARTMENT OF ENERGY, under

Interagency Agreement DE-AI08-86NV10583

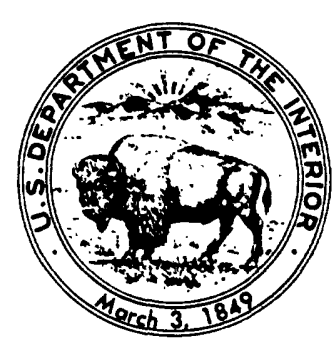

Carson City, Nevada 1992 


\section{U.S. DEPARTMENT OF THE INTERIOR}

MANUEL LUJAN, JR., Secretary

\section{U.S. GEOLOGICAL SURVEY}

Dallas L. Peck, Director

Any use of trade, product, or firm names in this publication is for descriptive purposes only and does not constitute endorsement by the U.S. Government.

For additional information write to:

\section{District Chief}

U.S. Geological Survey

333 W. Nye Lane, Room 206

Carson City, NV 89706
Copies of this report may be purchased from:

U.S. Geological Survey

Books and Open-File Reports Section

Federal Center

Box 25425

Denver, CO 80225 


\section{CONTENTS}

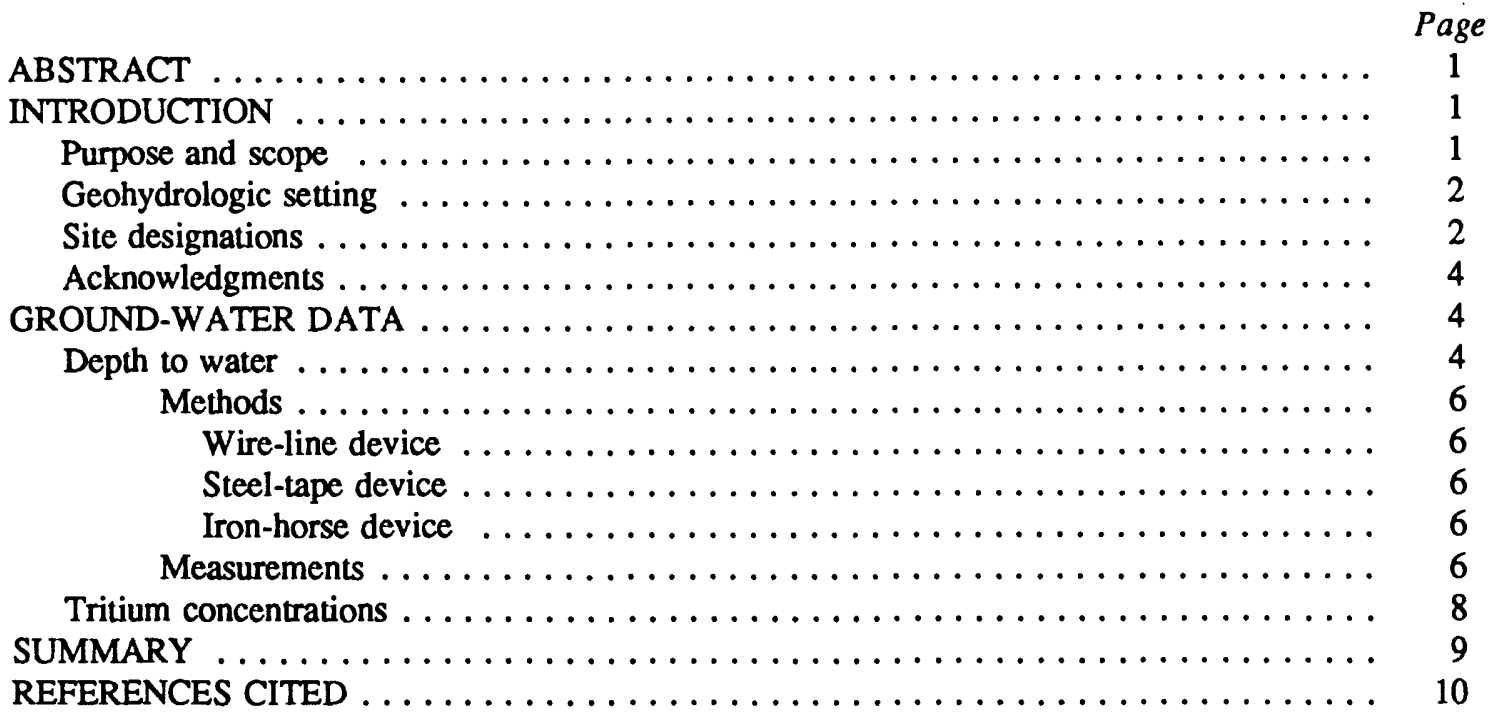

\section{ILLUSTRATIONS}

Plate 1. Location map of wells and test holes at the Nevada Test Site, Nye County, Nevada [in pocket at back of report]

Figure 1. Map showing location of Nevada Test Site and Faultless Site . . . . . . . . 3

2. Map showing location of test holes at Faultless Site, Nye County, Nevada . . . . . 5

3-14. Hydrographs showing depth-to-water measurements in:

3. Test hole UE-18r on Buckboard Mesa $\ldots \ldots \ldots \ldots \ldots \ldots \ldots \ldots \ldots \ldots$

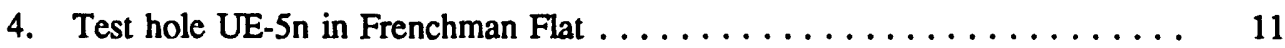

5. Test hole HTH-1 in Hot Creek Valley . . . . . . . . . . . . . . . 12

6. Test hole HTH-2 in Hot Creek Valley .................. 12

7. Test hole UC-1-P-2SR in Hot Creek Valley $\ldots \ldots \ldots \ldots \ldots \ldots \ldots \ldots \ldots$

8. Well TW-F in Mercury Valley ...................... 13

9. Test hole PM-1 on Pahute Mesa $\ldots \ldots \ldots \ldots \ldots \ldots \ldots \ldots \ldots \ldots$

10. Test hole PM-2 on Pahute Mesa .................... 14

11. Test hole PM-3 on Pahute Mesa ................... 15

12. Well TW-7 in Yucca Flat ...................... 15

13. Test hole $U-3$ en 5 in Yucca Flat $\ldots \ldots \ldots \ldots \ldots \ldots \ldots \ldots \ldots \ldots \ldots . \ldots \ldots \ldots$

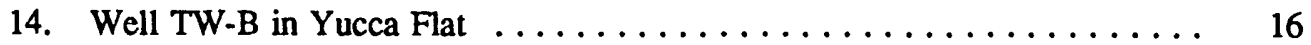

\section{TABLES}

Table 1. Depth to water in wells and test holes at the Nevada Test Site and the Faultless

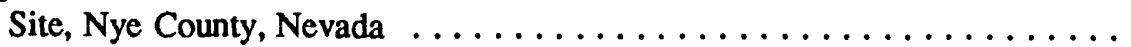

2. Tritium concentrations in water samples collected from test holes at the Nevada Test Site, Nye County, Nevada 
CONVERSION FACTORS AND ABBREVIATIONS

\begin{tabular}{lll}
\multicolumn{1}{c}{ Multiply } & \multicolumn{1}{c}{ By } & To obtain \\
curie (Ci) & $3.700 \times 10^{10}$ & becquerel \\
foot (ft) & 0.3048 & meter \\
gallon (gal) & 3.785 & liter \\
inch (in.) & 25.40 & millimeters \\
mile (mi) & 1.609 & kilometer \\
picocurie (pCi) & 0.0370 & becquerel
\end{tabular}

\section{SEA LEVEL}

In this report, "sea level" refers to the National Geodetic Vertical Datum of 1929 (NGVD, formerly called "Sea-Level Datum of 1929"), which is derived from a general adjustment of the firstorder leveling networks of both the United States and Canada. 


\title{
GROUND-WATER DATA COLLECTED \\ AT THE NEVADA TEST SITE AND VICINITY, NYE COUNTY, NEVADA, WATER YEARS 1988-89
}

\author{
By David B. Wood
}

\begin{abstract}
The U.S. Geological Survey, in support of the U.S. Department of Energy Hydrology/Radionuclide Migration Program, collects and compiles hydrologic and geohydrologic data to aid in characterizing the regional and local ground-water flow systems underlying the Nevada Test Site. This report presents selected ground-water data collected from wells and test holes at and in the vicinity of the Nevada Test Site.

Depth-to-water measurements were made at 72 sites and water samples were collected and analyzed for tritium concentrations for 14 sites during the 1988 and 1989 water years. Available historical data for these sites have been included to show the long-term depth-to-water fluctuations and to provide a record of all reported completion depths or open intervals for associated wells and test holes. Depth-to-water measurements show that the altitude of the ground-water surface in the Nevada Test Site area ranged from 1,966 to 6,377 feet above sea level. Depth-to-water measurements were obtained by a combination of wireline, steel-tape, and iron-horse methods. Tritium concentrations in bailed water samples ranged from -10 to 2,600 picocuries per liter.
\end{abstract}

\section{INTRODUCTION}

The Nevada Test Site (fig. 1) was established in 1950 as a continental proving ground for testing nuclear weapons (U.S. Congress, 1989). Atmospheric nuclear testing commenced in 1951 and underground nuclear testing commenced in 1957. Since 1962, all nuclear testing has been done underground (U.S. Department of Energy, 1988) and mostly in alluvium and volcanic rocks (U.S. Geological Survey, 1976). To determine whether radionuclides resulting from this testing are contained in the host rock or may migrate, an assessment of the ground-water systems is necessary.

The U.S. Geological Survey (USGS), Desert Research Institute, Los Alamos National Laboratory, and Lawrence Livermore National Laboratory are the principal organizations that provide services and technical expertise to the Nevada Field Office of the U.S. Department of Energy in support of the Hydrology/ Radionuclide Migration Program at the Nevada Test Site. The purpose of the Hydrology/Radionuclide Migration Program is to document the mechanisms by which radionuclides produced by underground nuclear tests may move through the geologic media and the direction and extent of such movement. The specific responsibility of the USGS in support of the Hydrology/Radionuclide Migration Program is to provide the necessary hydrologic and geohydrologic data and the interpretation of these data to aid in characterizing the regional and local ground-water flow systems. This characterization is needed to assess the potential for radionuclide migration.

\section{Purpose and Scope}

This report presents ground-water data collected at and in the vicinity of the Nevada Test Site from October 1, 1987, to September 30, 1989 (water years 1988 and 1989). More specifically, this report presents depth-to-water measurements collected at all accessible wells and test holes in two discrete study areas--the Nevada Test Site and the Faultless Site (fig. 1). Available historical depth-to-water measurements (prior to October 1, 1987) for sites measured during the 1988 and 1989 water years have been included to 
indicate fluctuations in depth to water through time. The Nevada Test Site, subdivided into 27 administrative areas (pl. 1), is between latitudes 36 and 38 degrees north and longitudes 115 and 117 degrees west. The Faultless Site in Hot Creek Valley (fig. 2) is between latitudes 38 and 39 degrees north and longitudes 116 and 117 degrees west. Both areas are in Nye County, Nev. (fig. 1).

Depth-to-water measurements were made at 72 wells and test holes, and water samples were collected from 14 test holes and analyzed for tritium concentration at the Environmental Monitoring Systems Laboratory of the U.S. Environmental Protection Agency in Las Vegas, Nev. Depth-to-water data have been collected, compiled, verified, and stored in the Ground-Water Site Inventory (GWSI) data base. This is one of four subsystems that constitute the computerized National Water Information System (NWIS) of the USGS, managed in Nevada by the District Office in Carson City, Nev.

The Department of Energy Yucca Mountain Project study area is located in and adjacent to Areas 25 and 29 of the Nevada Test Site (pl. 1). Ground-water data collected from those areas are compiled and reported by USGS personnel of the Nuclear Hydrology Program assigned to the Yucca Mountain Project (Robison and others, 1988; Gemmell, 1990; O'Brien, 1991).

\section{Geohydrologic Setting}

The geohydrologic setting of the Nevada Test Site is similar to that of most of the Basin and Range Province. It is characterized by local aquifers within the basin-fill deposits and volcanic rocks. Regional aquifers are mostly within complexly folded and faulted limestones and dolomites (Winograd and Thordarson, 1975), but may exist within deep fractured volcanic rocks at some locations (Blankennagel and Weir, 1973). Much of the ground-water flow is interbasin, that is, deep ground-water flow is not controlled by the basin-and-range topography that defines surface drainage basins (Winograd and Thordarson, 1975).

\section{Site Designations}

Ground-water sites are either wells or test holes. The term "well" describes cased holes drilled specifically to find ground water. All other drilled holes are termed test holes. Wells and test holes are identified herein by Fenix and Scisson of Nevada (FSN; now Raytheon Services Nevada) hole number, by USGS site identification number, and by the latitude and longitude of the site.

The FSN hole numbers are assigned by Fenix and Scisson of Nevada to wells and test holes according to the type of hole drilled, site location (Nevada Test Site Area, pl. 1), and sequence code for the consecutive order in which the hole was drilled or redrilled. Emplacement holes for nuclear weapons tests begin with the letter "U," followed by a dash (-), Nevada Test Site area number (pl. 1), and sequence code (letters "a-z, aa-az, ba-bz, ..., za-zz"). A hole drilled specifically to provide data that could not be collected from an emplacement hole is assigned incremental letters or numbers, or both. The suffix letters "ITS" indicate an integrated test system, "PS" a post shot hole, "S" a substitute hole, and "WW" a water well. Exploratory holes follow the same naming convention, but begin with the letters "UE."

In this report, exceptions to the standard assignment procedures are Army $1 \mathrm{WW}, \mathrm{HTH}-1, \mathrm{HTH}-2$, PM-1, PM-2, PM-3, TW-1, TW-7, TW-B, TW-D, TW-F, and UC-1-P-2SR. The prefix letters "HTH" indicate a hydrologic test hole, "PM" Pahute Mesa, "TW" a test well, and "UC" underground central Nevada. Numbers and letters following the dash in the exceptions represent sequence of site drilling, not Nevada Test Site area location. 


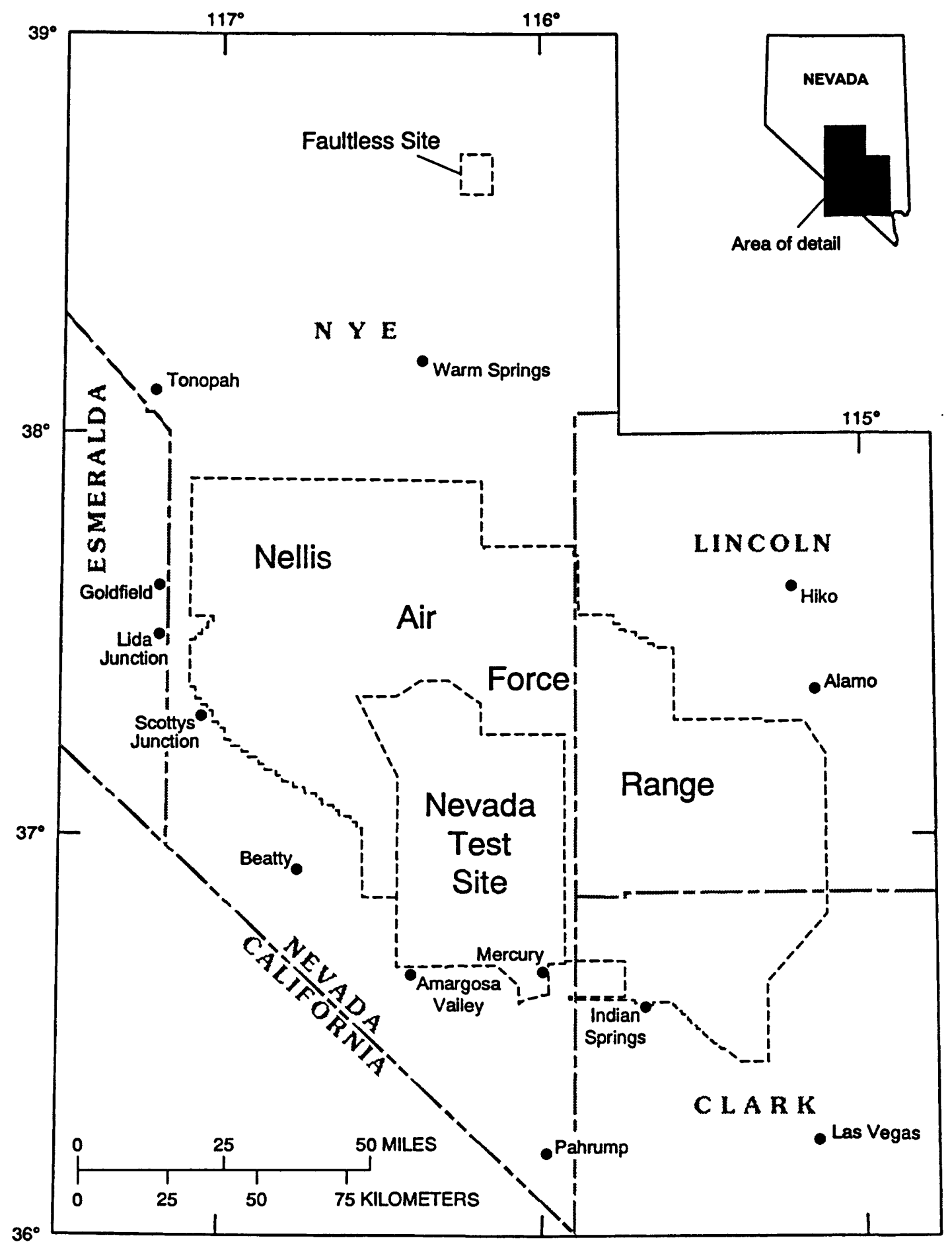

Base from U.S. Geological Survey digital data, 1:100,000, 1979-86 Universal Transverse Mercator projection,

Zone 11

FIGURE 1.--Location of Nevada Test Site and Faultless Site. 
The USGS system for site identification is based on the latitude-longitude grid. Each site is identified by a unique 15-digit number: The first six digits are the degrees, minutes, and seconds of latitude; the next seven digits are the degrees, minutes, and seconds of longitude; and the last two digits constitute the sequence number of the well or test hole within the 1-second grid of latitude and longitude. The assigned number is retained as a permanent identifier even if a more precise latitude and longitude are later determined (U.S. Geological Survey, 1989, p. 2-10). Therefore, to determine the geographic location of a well or test hole, the latitude and longitude coordinates (which are listed herein) should be used rather than the site identifier.

\section{Acknowledgments}

Several organizations under contract with the Nevada Field Office of the U.S. Department of Energy made substantial contributions, including field inventory of wells and test holes and other hydrologic work. These contractors were: Holmes and Narver, Inc.; Fenix and Scisson of Nevada (now Raytheon Services Nevada); Welex; and Atlas Wireline Services (formerly Dresser Atlas Industries, Inc.). The Environmental Monitoring Systems Laboratory of the U.S. Environmental Protection Agency at Las Vegas also provided data.

\section{GROUND-WATER DATA}

Data presented consist of depth-to-water measurements for all accessible wells and test holes and tritium concentrations for all accessible test holes. During the 1988 and 1989 water years, depth to water was measured at 72 wells and test holes and tritium concentrations were analyzed for water samples collected from 14 test holes. The locations of these wells and test holes are shown on plate 1 and figure 2 .

The data-collection network consists basically of two parts--short-term test holes and long-term observation wells and test holes. Depth to water in them is measured intermittently in all accessible test holes that penetrate the saturated zone. These measurements are made frequently until the measured depth to water stabilizes or the hole is destroyed or becomes inaccessible. The majority of test holes are shortterm holes and the opportunity to measure depth to water in them is limited to a few weeks or a few months, which is often not sufficient for stabilization of depth to water. Because most of the existing observation wells and test holes available for long-term observation were not drilled for the direct acquisition of hydrologic data, it often is not possible to monitor depth-to-water fluctuations that represent local (basin-fill or volcanic-rock) or regional (carbonate-rock) aquifer conditions. Wells or test holes that exhibit minor fluctuations in depth to water are measured annually. Wells or test holes that exhibit large fluctuations in depth to water are measured weekly, quarterly, or continuously.

\section{Depth to Water}

The term "depth to water" is used rather than "water level" to avoid confusion with "static water level" as defined by Winograd (1970, p. 19) for the Nevada Test Site. Use of depth to water does not imply static conditions. Test holes drilled for nuclear weapons tests commonly become inaccessible prior to fluidlevel stabilization. Depth-to-water measurements in wells and test holes often represent elevated or depressed fluid levels because of drilling methods or nearby nuclear detonations (Winograd, 1970, p. 20-25). Measurements may be affected by removal or injection of fluid or may represent a composite fluid level for the saturated units penetrated.

Water-level altitudes determined by subtracting depth-to-water measurements from the reported landsurface altitude may not represent actual water-level altitudes. The altitude of land surface is determined by conventional surveying techniques at each well or test hole when drilling operations have been completed. The reported land-surface altitude subsequently may have been altered as a result of nuclear testing. 


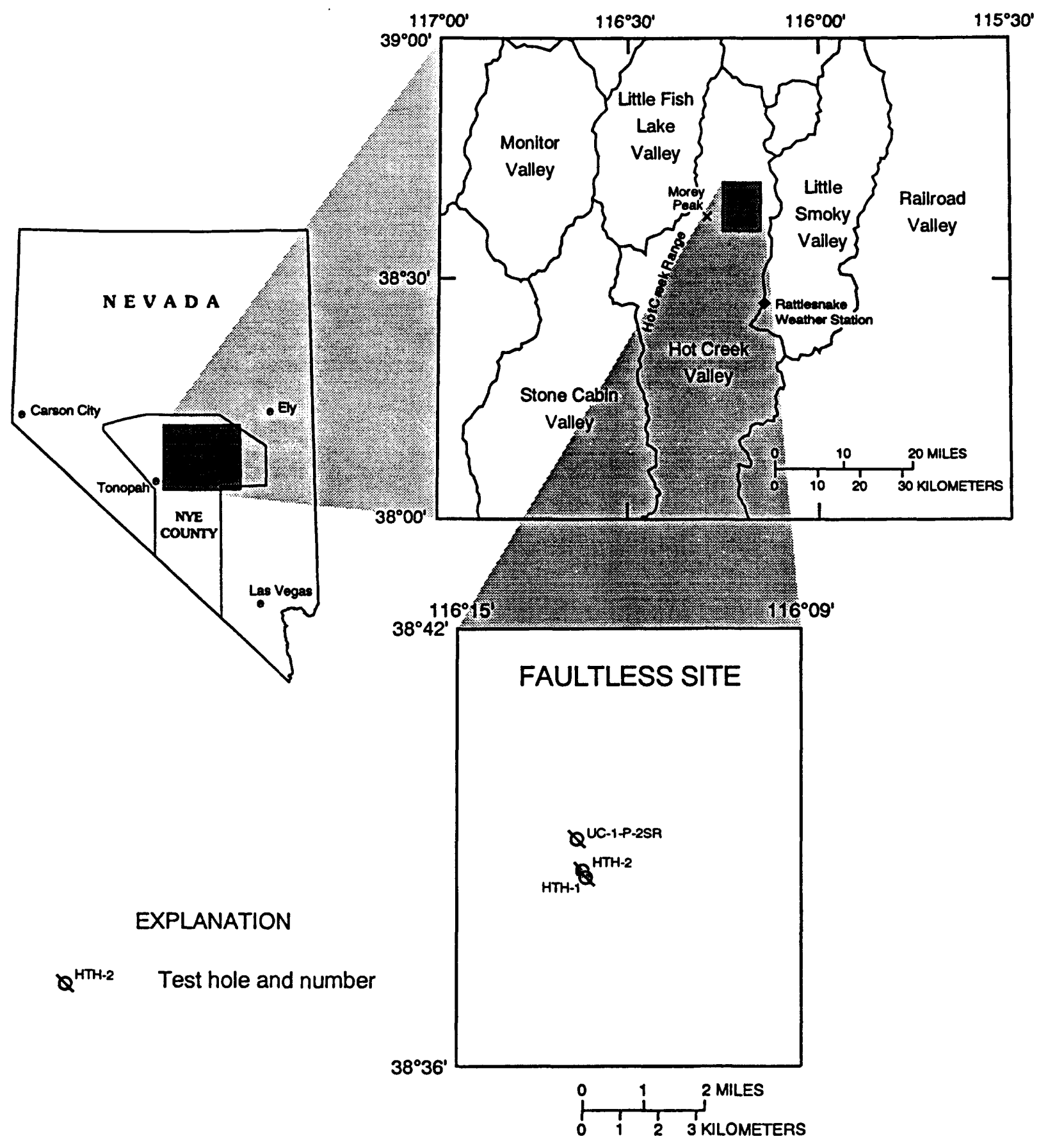

FIGURE 2.--Location of test holes at Faultless Site, Nye County, Nevada. Modified from Thordarson (1987, figure 1). 


\section{Methods}

Several techniques are used to measure depth to water at the Nevada Test Site. Currently, measurements are made by the USGS with a wire-line device. Steel-tape measurements are used to calibrate the wire-line device. Historical measurements were made with an iron-horse device and a steel tape.

\section{Wire-Line Device}

The wire-line device consists of an armored four-conductor cable contained on a motorized reel. For depth-to-water measurements, the cable is centered over and guided into the well or test hole with a hydraulic boom. Attached to the end of the cable is a probe that transmits an electric current to a meter at land surface the instant water or fluid is contacted. A measuring wheel, over which the cable passes, measures the length of cable withdrawn from the well or test hole.

\section{Steel-Tape Device}

The technique used for making steel-tape measurements of depth to water greater than 1,000 feet below land surface described by Garber and Koopman (1968, p. 2-6) has been modified as described by Robison and others (1988, p. 9-10). The steel tape, which is mounted on a motor driven reel, is suspended in the well or test hole a known distance below a reference mark so the bottom end is below the water or fluid surface. The length of wetted tape is subtracted from the suspended length below the reference mark and adjusted to land-surface datum by subtracting or adding the distance of the reference point above or below land surface to determine the measured depth to water.

\section{Iron-Horse Device}

The technique for using the iron-horse device to measure depth to water has been described by Garber and Koopman (1968, p. 6-11) and by Weir and Nelson (1976). The device consists of an armored singleconductor cable mounted on a portable reel. Attached to the end of the cable is a probe that transmits an electric current to a meter at land surface the instant water or fluid is contacted. A measuring wheel, over which the cable passes, measures the length of cable withdrawn from the well or test hole.

\section{Measurements}

Depth-to-water measurements for wells and test holes shown in table 1 represent all data compiled in the GWSI data base as of September 30, 1990; therefore, measurements made in the 1988 and 1989 water years can be compared to earlier measurements. For selected wells and test holes, the following data are presented: Fenix and Scisson of Nevada (FSN) hole-number designation, USGS site identification number, latitude and longitude coordinates, date hole completed, land-surface altitude, hole depth, top of open interval, bottom of open interval, type of open interval, measurement date, depth-to-water measurement, measurement method, and measurement site status. Data are listed in table 1 sequentially, first by Nevada Test Site administrative area, then by FSN hole-number designation and USGS site-identification number within each area.

The measured altitude of the ground-water surface ranged from 1,966 feet above sea level on July 14, 1989, at UE-4av in Yucca Flat to 6,377 feet above sea level on September 20, 1988, at UE-12t 6 in Rainier Mesa. The depth to water ranged from 337 feet below land-surface altitude on January 22, 1968, at HTH-1 in Hot Creek Valley to 2,339 feet below land-surface altitude on April 11, 1970, at UC-1-P-2SR in Hot Creek Valley. The depth to water of 70 feet below land-surface altitude on September 19, 1988, at UE-12t 6 was excluded from comparisons because it represents depth to the surface of water added to the hole for an injection (slug) test. 
Twelve hydrographs of wells and test holes, figures 3-14, show changes in depth to water at various locations (pl. 1 and fig. 2; the hydrographs are grouped by geographic area and, within an area, by FSN hole-number designation). These selected hydrographs typify depth-to-water measurements within general geographic areas and rock types. Measurements affected by pumping or injection have been removed from the hydrographs. A brief description of each hydrograph follows:

Figure 3 shows depth-to-water measurements in UE-18r on Buckboard Mesa (Area 18). The test hole is open to Tertiary volcanic rocks, primarily tuff located in the moat area on the north flank of the Timber Mountain caldera.

Figure 4 shows depth-to-water measurements in UE-5n in Frenchman Flat (Area 5). The test hole is open to Quaternary alluvium.

Figure 5 shows depth-to-water measurements in HTH-1 in Hot Creek Valley. The test hole is open to Quaternary and Tertiary alluvium and Tertiary volcanic rocks, primarily tuff and tuffaceous sediments. The peak in the measurement record coincides with a nearby nuclear detonation--the Faululess event on January 19, 1968 (U.S. Department of Energy, 1988).

Figure 6 shows depth-to-water measurements in HTH-2 in Hot Creek Valley. The test hole is open to Quaternary and Tertiary alluvium. The peak in the measurement record coincides with the Faultless event.

Figure 7 shows depth-to-water measurements in UC-1-P-2SR in Hot Creek Valley. The test hole is open to Quaternary and Tertiary alluvium and Tertiary volcanic rocks, primarily tuff consisting of rubble caused by the collapse of the cavity formed by the Faultless event. Measurements of static depths to water prior to September 24, 1974, represent a zone of perched water (Thordarson, 1987). Decreases in depth to water from September 1974 to the present are attributed to infilling of the cavity.

Figure 8 shows depth-to-water measurements in TW-F in Mercury Valley (Area 27). The well is open to Paleozoic carbonate rocks, primarily dolomite.

Figure 9 shows depth-to-water measurements in PM-1 on Pahute Mesa (Area 20). The test hole is open to Tertiary volcanic rocks, primarily tuff and rhyolite. Differences in depth to water measured at two completion depths are presented. Measurements prior to September 25, 1963, were made when the hole depth was 7,552 feet. Measurements from January 4, 1981, were made when the hole depth was 7,731 feet.

Figure 10 shows depth-to-water measurements in PM-2 on Pahute Mesa (Area 20). The test hole is open to Tertiary volcanic rocks, primarily tuff, rhyolite, and dacite.

Figure 11 shows depth-to-water measurements in PM-3 on Pahute Mesa adjacent to the Nevada Test Site. The test hole is open to Tertiary volcanic rocks, primarily tuffs. Differences in depth to water measured at two completion depths are presented. Measurements prior to September 14, 1988, were made when the hole depth was 1,647 feet. Measurements from September 21,1988 , were made when the hole depth was 3,019 feet.

Figure 12 shows depth-to-water measurements in TW-7 in Yucca Flat (Area 3). The well is open to Tertiary volcanic rocks, primarily tuff. Two peaks in the measurement record coincide with nearby nuclear detonations (M.S. Garber, U.S. Geological Survey, written commun., 1963 and 1965)--the Aardvark event on May 12, 1962 and the Bilby event on September 13, 1963 (U.S. Department of Energy, 1988). 
Figure 13 shows depth-to-water measurements in U-3en 5 in Yucca Flat (Area 3). The test hole is open to Paleozoic carbonate rocks.

Figure 14 shows depth-to-water measurements in TW-B in Yucca Flat (Area 6). The well is open to Tertiary volcanic rocks, primarily tuff. Long-term records of measurements are presented.

\section{Tritium Concentrations}

Water samples for tritium concentrations were collected from 14 test holes at the Nevada Test Site. Raw, unfiltered samples were collected in 500-milliliter acid-rinsed glass bottles, labeled, and delivered to the Environmental Monitoring Systems Laboratory of the U.S. Environmental Protection Agency in Las Vegas, Nev. The results of the tritium analyses are presented in table 2. For the 14 test holes, the following information is listed: Fenix and Scisson of Nevada (FSN) hole-number designation, USGS site identification number, latitude and longitude coordinates, date hole completed, land-surface altitude, hole depth, top of open interval, bottom of open interval, type of open interval, measurement date, and tritium concentration. Some tritium concentrations may represent residual drilling fluids or other fluids introduced during drilling or pumping and water injection instead of representing water solely from the saturated zone. Tritium concentrations ranged from $-10 \mathrm{pCi} / \mathrm{L}$ on March 8, 1989, at U-20bd on Pahute Mesa, to $2,600 \mathrm{pCi} / \mathrm{L}$ on April 5, 1988, at U-4au on Yucca Flat. An average annual concentration of $20,000 \mathrm{pCi} / \mathrm{L}$ of tritium in drinking water is the maximum permissible limit established by the U.S. Environmental Protection Agency in Title 40 Code of Federal Regulations (1988). None of the tritium concentrations exceeded this limit.

The U.S. Environmental Protection Agency, under an interagency agreement with the Department of Energy, is responsible for evaluating human radiation exposure from ingesting air, water, and food that may have been affected by nuclear testing (U.S. Congress, 1989). Tritium concentration data are collected at and in the vicinity of the Nevada Test Site and reported annually by the Environmental Monitoring Systems Laboratory at Las Vegas, Nev., as part of the long-term hydrological monitoring program conducted by the U.S. Environmental Protection Agency to fulfill this commitment (U.S. Environmental Protection Agency, 1989, p. 83-109).

A bailer was used to collect water samples from below the water surface in the test holes. The technique used to collect the samples is described by Claassen (1982, p. 36-38) and by Wood (1976, p. 5-6). The bailer used in 1988 and 1989 was a solid plug coupled to a 1-9/16-inch (inside diameter) by 6-foot-long stainless steel tube coupled to a 2-foot-long upper section containing four 3/4-inch by 6-inch slots and coupled to a solid cap. Each bailed sample contained about $1 / 2$ gallon of water. To prevent possible crosscontamination, the bailer was rinsed twice with a 10-percent hydrochloric acid solution. The bailer then was rinsed twice with tap water or deionized water and allowed to air dry prior to the next sample collection. 


\section{SUMMARY}

The USGS, in support of the U.S. Department of Energy Hydrology/Radionuclide Migration Program, collects and compiles hydrologic and geohydrologic data at and in the vicinity of the Nevada Test Site to aid in characterizing the regional and local ground-water flow systems. This report presents depth-to-water measurements and tritium concentrations determined for selected wells and test holes as part of this program. Data collected as part of the Yucca Mountain Project at the Nevada Test Site are not included in this report.

Depth to water was measured at 72 sites, and water samples were collected and analyzed for tritium at 14 sites during the period of October 1,1987, to September 30,1989. The measured altitude of the water surface ranged from 1,966 feet above sea level at UE-4av to 6,377 feet above sea level at UE-12t 6 . The depth to water ranged from 337 feet below land surface at HTH-1 to 2,339 feet below land surface at UC-1-P-2SR. Hydrographs of depth to water measured at TW-7 in Yucca Flat and at UC-1-P-2SR in Hot Creek Valley show changes in depth to water in response to nuclear detonations. Hydrographs of depth to water at other sites indicate little or no change for the available period of record. Accessible wells and test holes are used to collect data needed to monitor regional and local ground-water conditions. The wire-line, steel-tape, and iron-horse techniques were used to measure depth to water. Tritium concentrations in water samples collected from selected test holes penetrating the saturated zone ranged from $-10 \mathrm{pCi} / \mathrm{L}$ at $\mathrm{U}-20 \mathrm{bd}$ to 2,600 $\mathrm{pCi} / \mathrm{L}$ at $\mathrm{U}-4 \mathrm{au}$ and did not exceed established drinking-water standards. 


\section{REFERENCES CITED}

Blankennagel, R.K., and Weir, J.E., Jr., 1973, Geohydrology of the eastern part of Pahute Mesa, Nevada Test Site, Nye County, Nevada: U.S. Geological Survey Professional Paper 712-B, 35 p.

Claassen, H.C., 1982, Guidelines and techniques for obtaining water samples that accurately represent the water chemistry of an aquifer: U.S. Geological Survey Open-File Report 82-1024, 49 p.

Code of Federal Regulations, 1988, Title 40, Section - 141, Drinking Water Regulations: Federal Register, Volume 41.

Garber, M.S., and Koopman, F.C., 1968, Methods of measuring water levels in deep wells: U.S. Geological Survey Techniques of Water-Resources Investigations, Book 8, Chapter A1, 23 p.

Gemmell, J.M., 1990, Water levels in periodically measured wells in the Yucca Mountain area, Nevada, 1988: U.S. Geological Survey Open-File Report 90-113, 47 p.

O'Brien, G.M., 1991, Water levels in periodically measured wells in the Yucca Mountain area, Nevada, 1989: U.S. Geological Survey Open-File Report 91-178, 51 p.

Robison, J.H., Stephens, D.M., Luckey, R.R., and Baldwin, D.A., 1988, Water levels in periodically measured wells in the Yucca Mountain area, Nevada, 1981-87: U.S. Geological Survey Open-File Report 88-468, 132 p.

Thordarson, William, 1987, Hydrogeology of the Faultless Site, Nye County, Nevada: U.S. Geological Survey Water-Resources Investigations Report 86-4342, $40 \mathrm{p}$.

U.S. Congress, 1989, The containment of underground nuclear explosions: Office of Technology Assessment Report OTA-ISC-414, 80 p.

U.S. Department of Energy, 1988, Announced United States nuclear tests, July 1945 through December 1987: Nevada Operations Office, Office of Public Affairs Report NVO-209, Revision 8, 66 p.

U.S. Environmental Protection Agency, 1989, Off-site environmental monitoring report; radiation monitoring around United States nuclear test areas, calendar year 1988: U.S. Environmental Protection Agency, Environmental Systems Laboratory, Las Vegas, Nev., $136 \mathrm{p}$.

U.S. Geological Survey, 1976, Field trip to Nevada Test Site: U.S. Geological Survey Open-File Report 76$313,64 \mathrm{p}$.

----1989, National water information system user's manual, v. 2, ch. 4--ground-water site inventory system: U.S. Geological Survey Open-File Report 89-587, 283 p.

Weir, J.E. Jr., and Nelson, J.W., 1976, Operation and maintenance of a deep-well water-level measurement device, the "iron horse": U.S. Geological Survey Water-Resources Investigations 76-27, 28 p.

Winograd, I.J., 1970, Noninstrumental factors affecting measurement of static water levels in deeply buried aquifers and aquitards, Nevada Test Site: Ground Water, v. 8, no. 2, p. 19-28.

Winograd, I.J., and Thordarson, William, 1975, Hydrogeologic and hydrochemical framework, south-central Great Basin, Nevada-California, with special reference to the Nevada Test Site: U.S. Geological Survey Professional Paper 712-C, 126 p.

Wood, W.W., 1976, Guidelines for collection and field analysis of ground-water samples for selected unstable constituents: U.S. Geological Survey Techniques of Water-Resources Investigations, Book 1, Chapter D2, 24 p. 


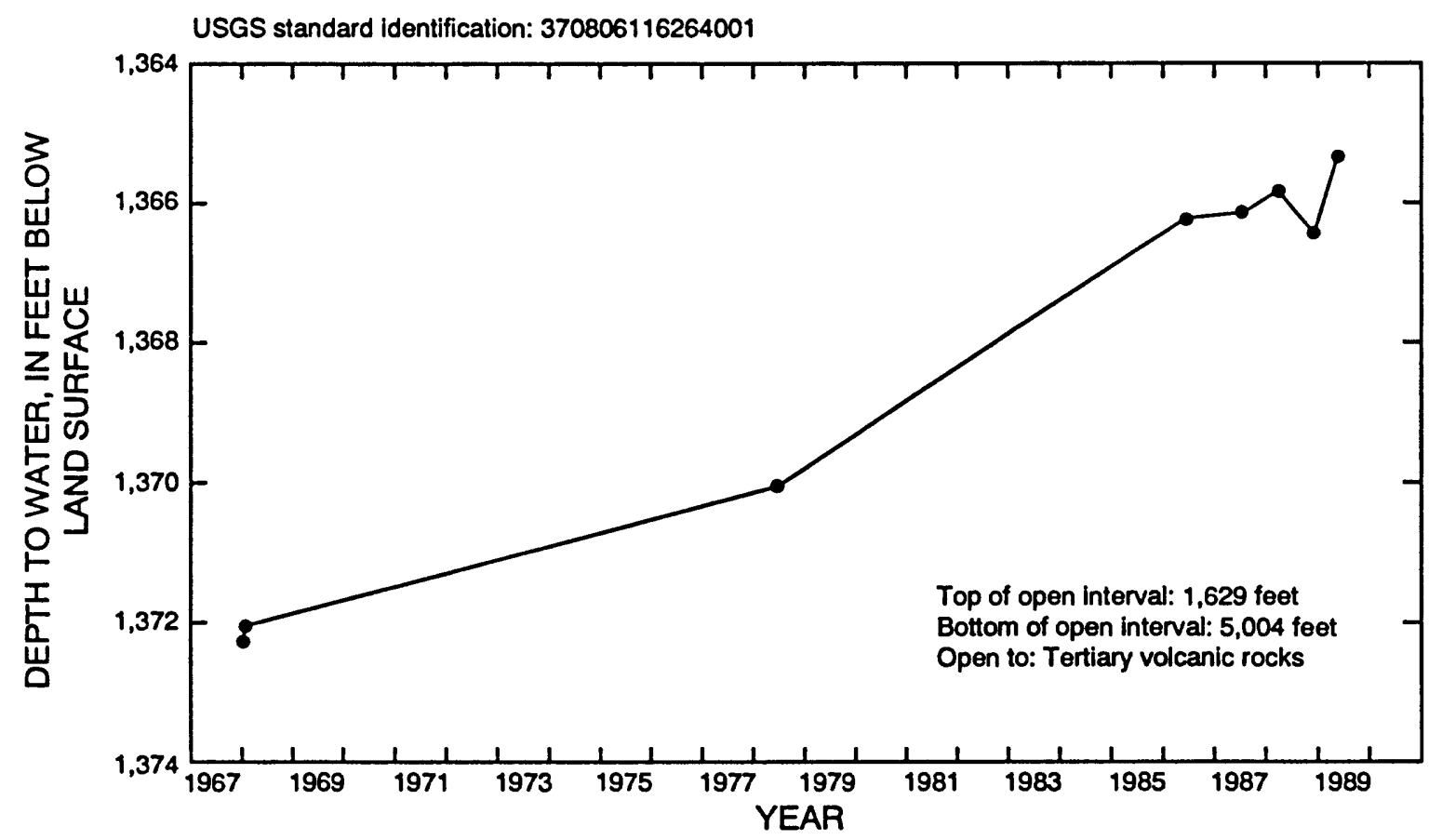

FIGURE 3.--Depth-to-water measurements in test hole UE-18r on Buckboard Mesa.

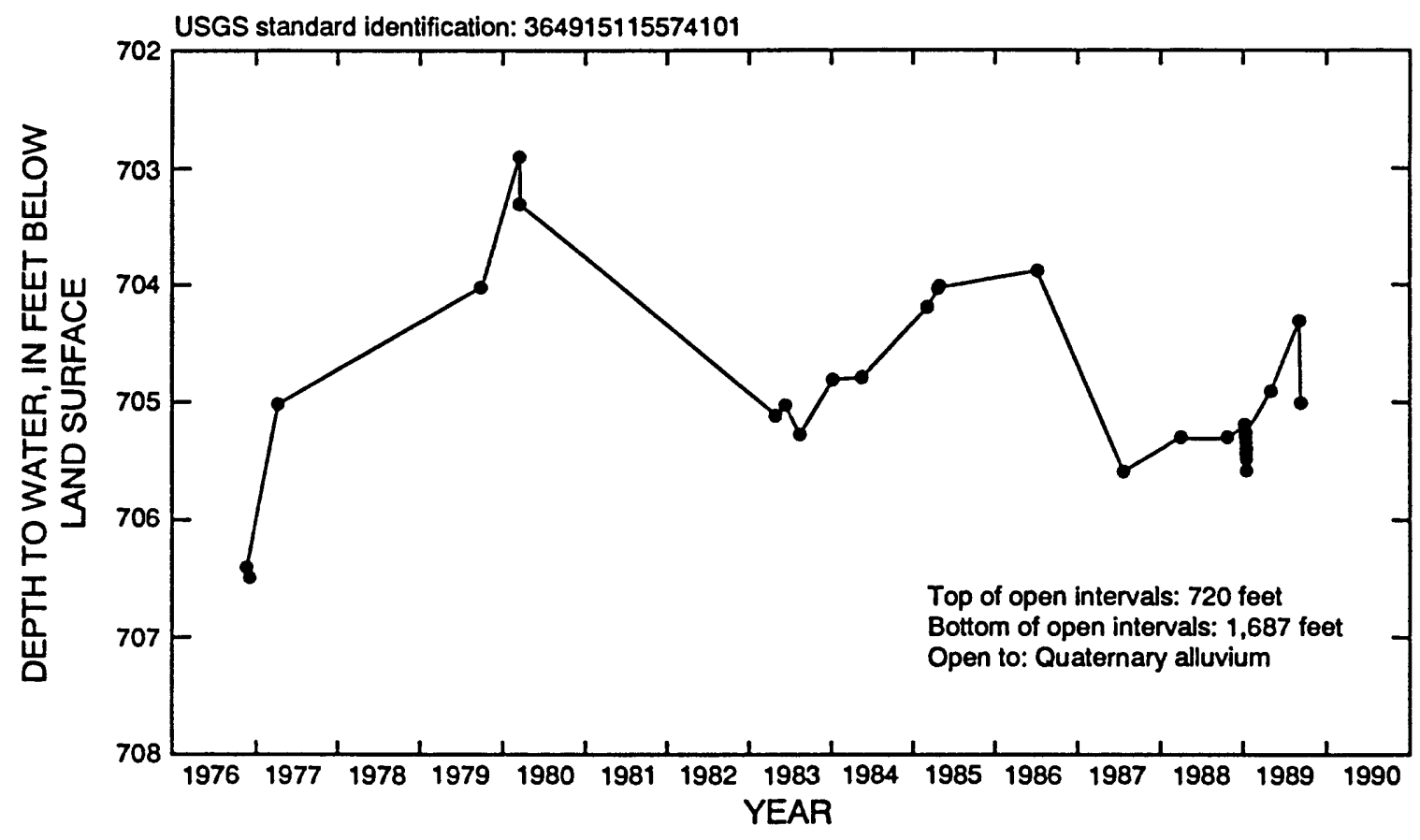

FIGURE 4.--Depth-to-water measurements in test hole UE-5n in Frenchman Flat. 


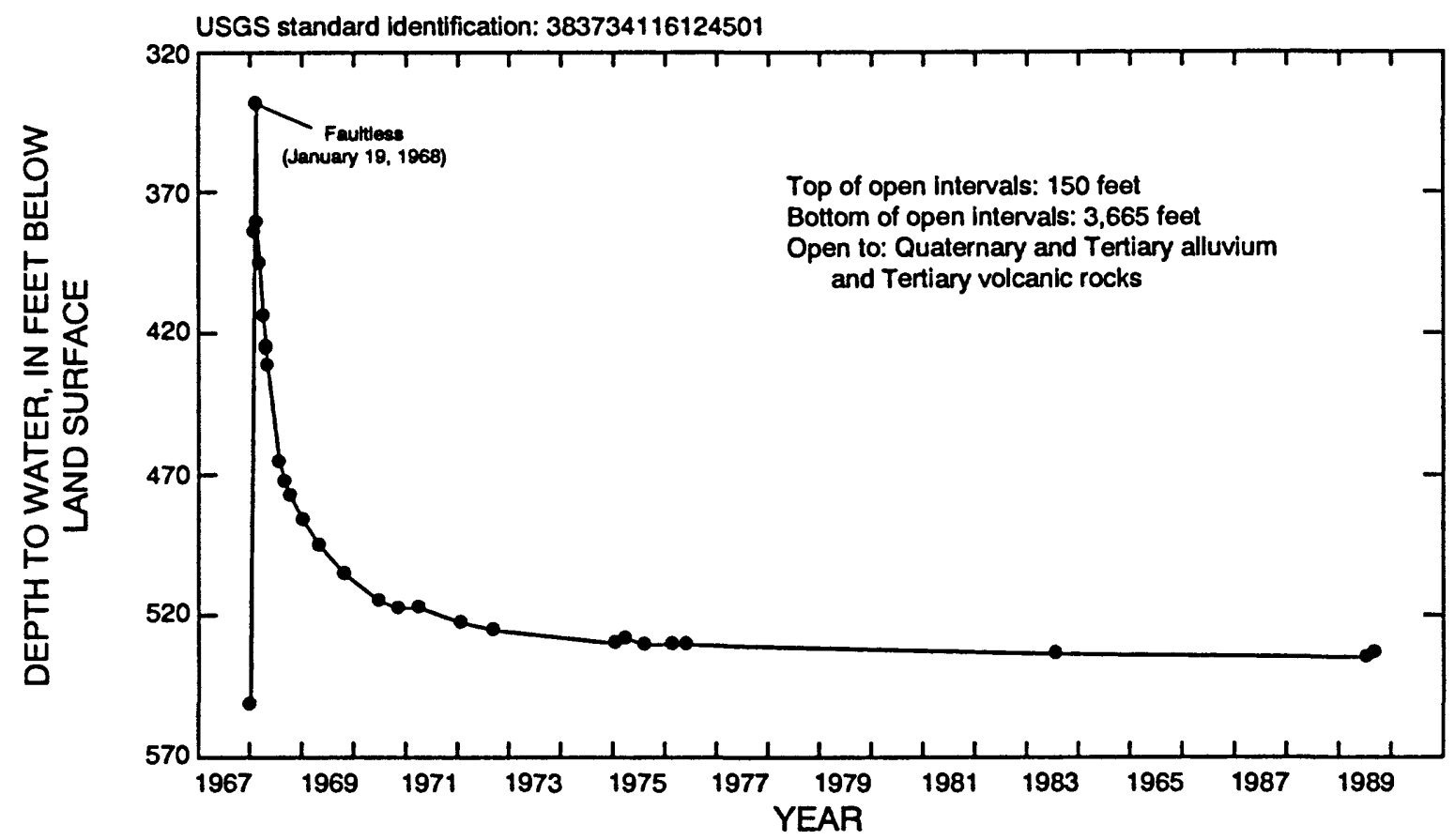

FIGURE 5.--Depth-to-water measurements in test hole HTH-1 in Hot Creek Valley. Name and date are indicated for nearby weapons test.

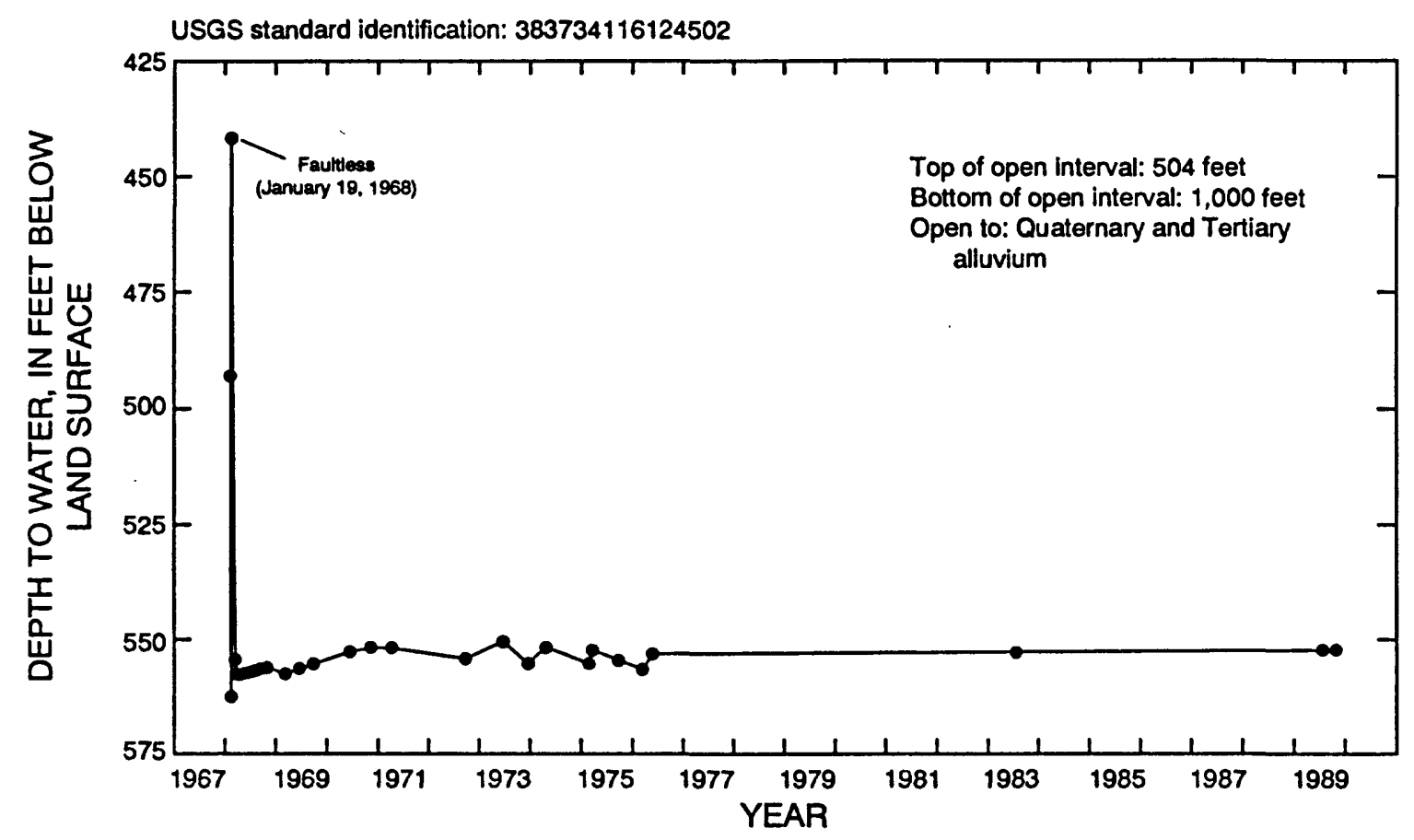

FIGURE 6.--Depth-to-water measurements in test hole HTH-2 in Hot Creek Valley. Name and date are indicated for nearby weapons test. 


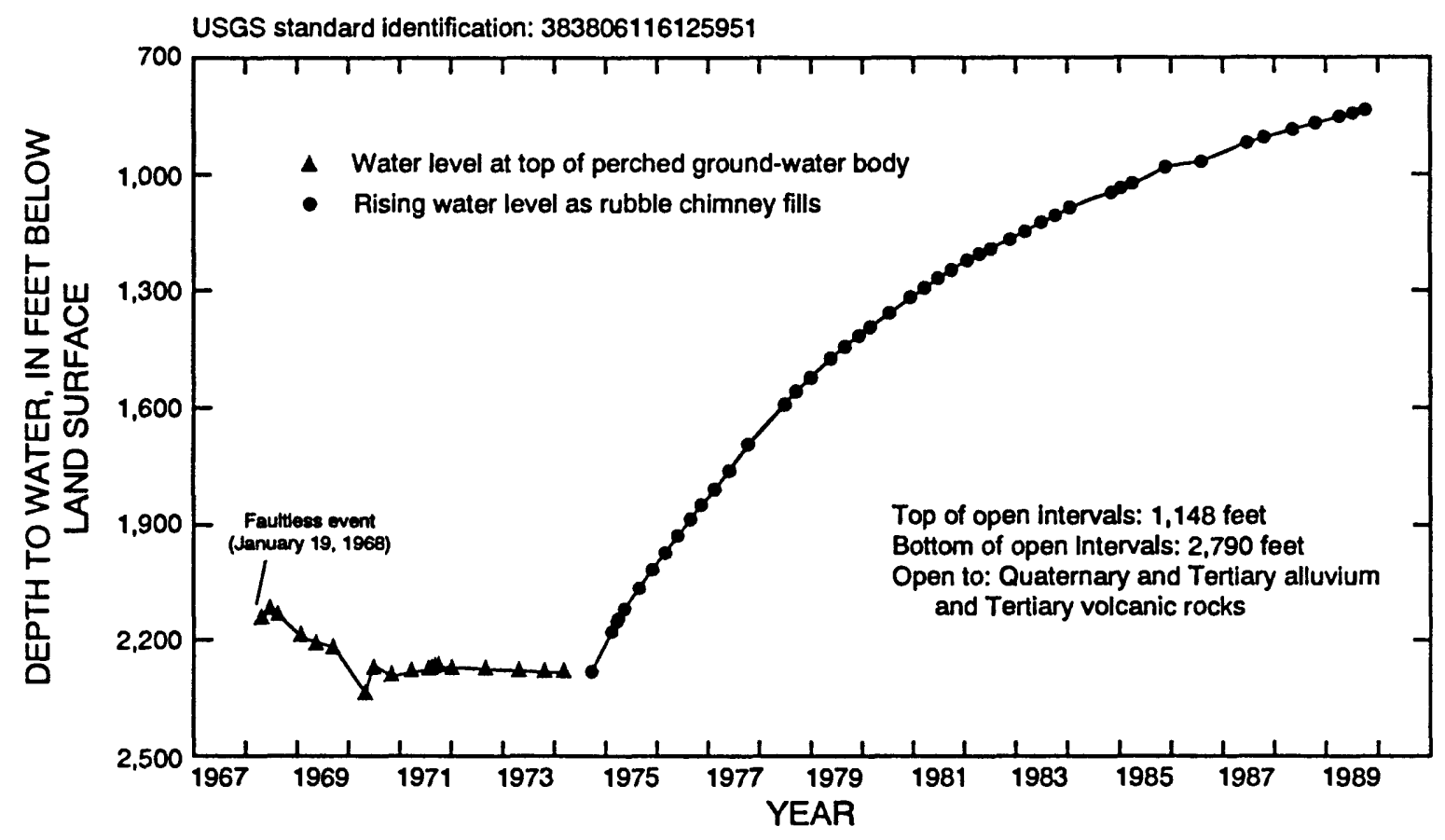

FIGURE 7.--Depth-to-water measurements in test hole UC-1-P-2SR in Hot Creek Valley (see Thordarson, 1987, p. 12-15). Name and date are indicated for nearby weapons test.

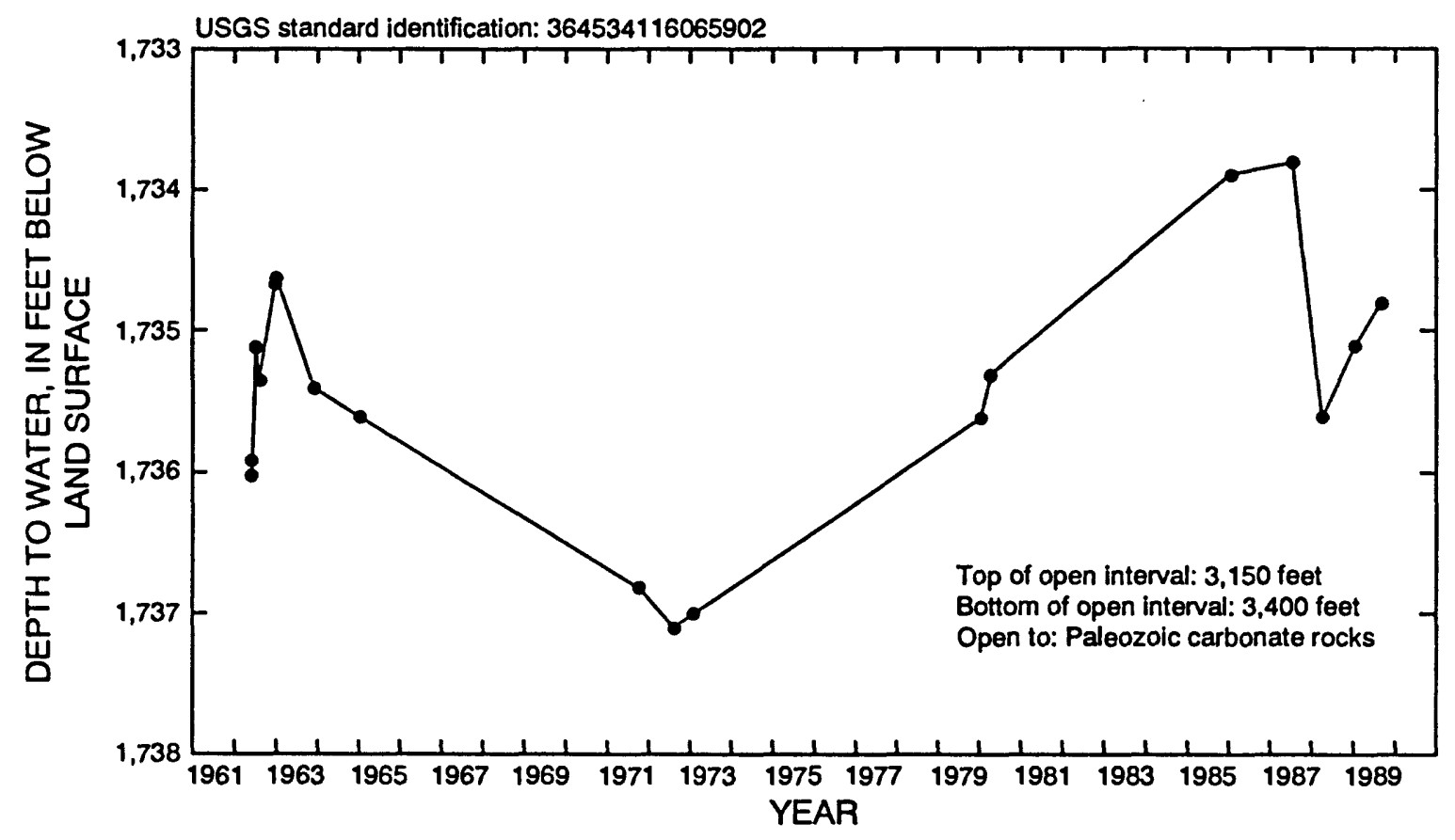

FIGURE 8.--Depth-to-water measurements in well TW-F in Mercury Valley. 


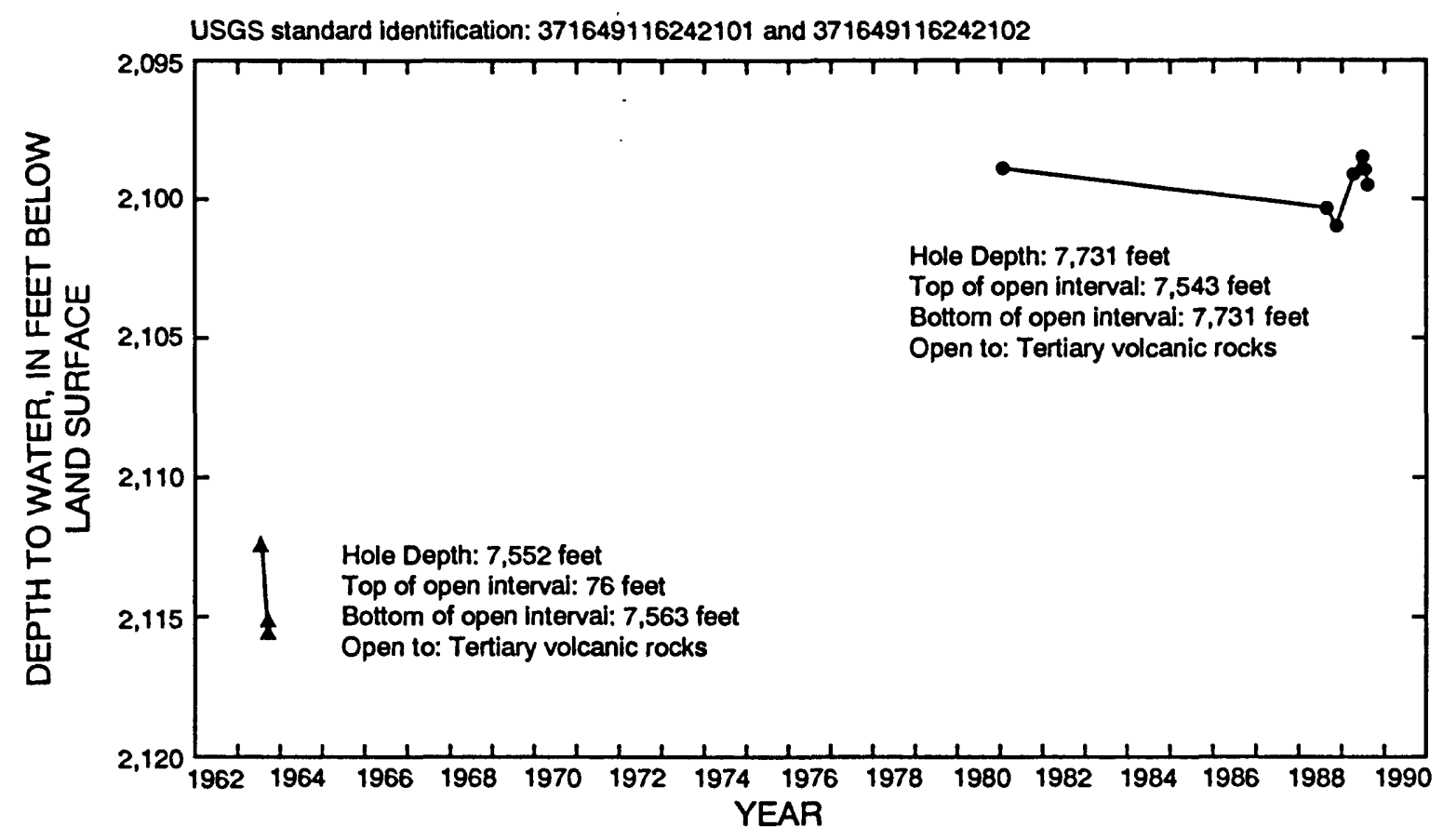

FIGURE 9.--Depth-to-water measurements at two completion depths in test hole PM-1 on Pahute Mesa.

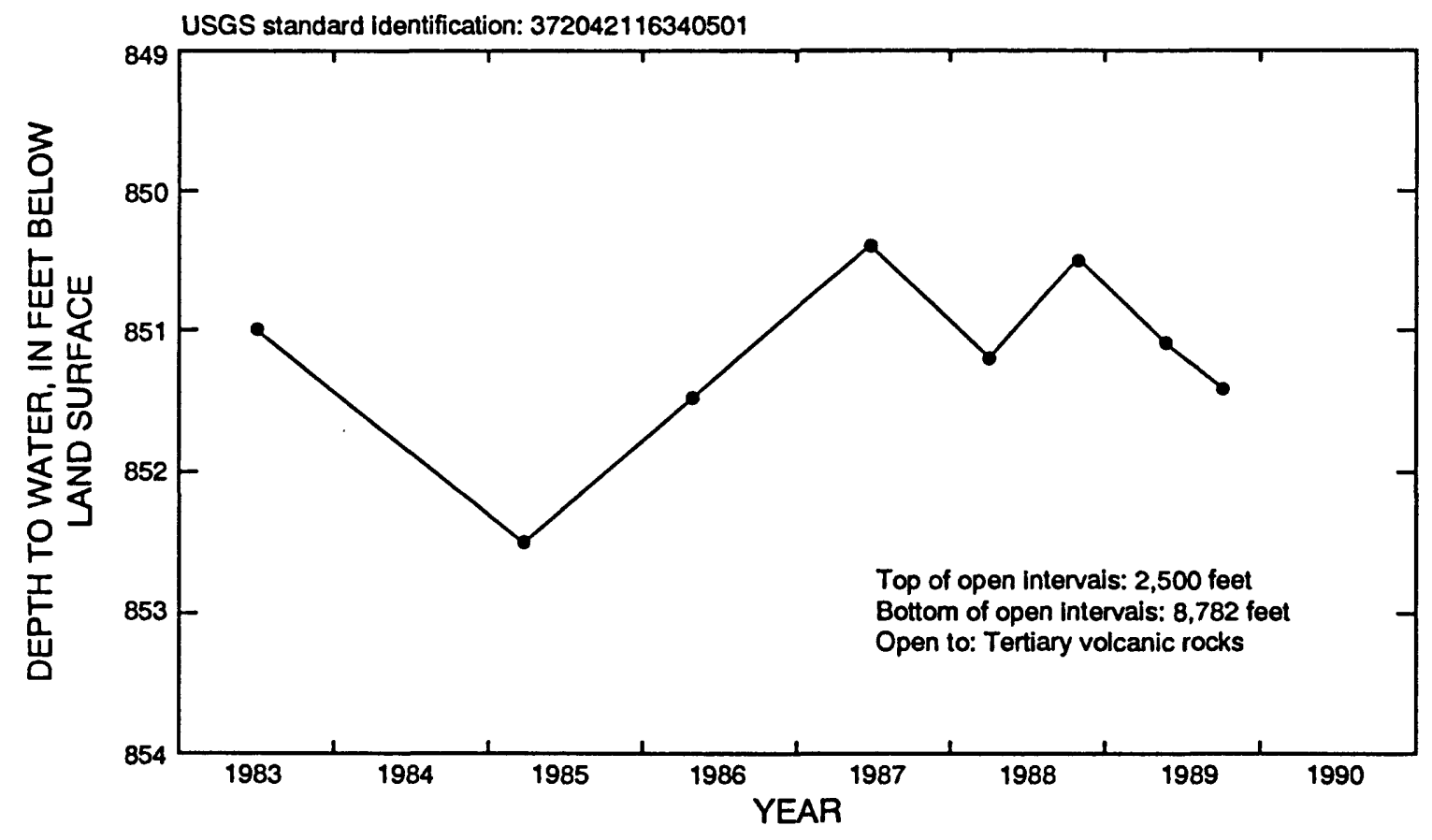

FIGURE 10.--Depth-to-water measurements in test hole PM-2 on Pahute Mesa. 


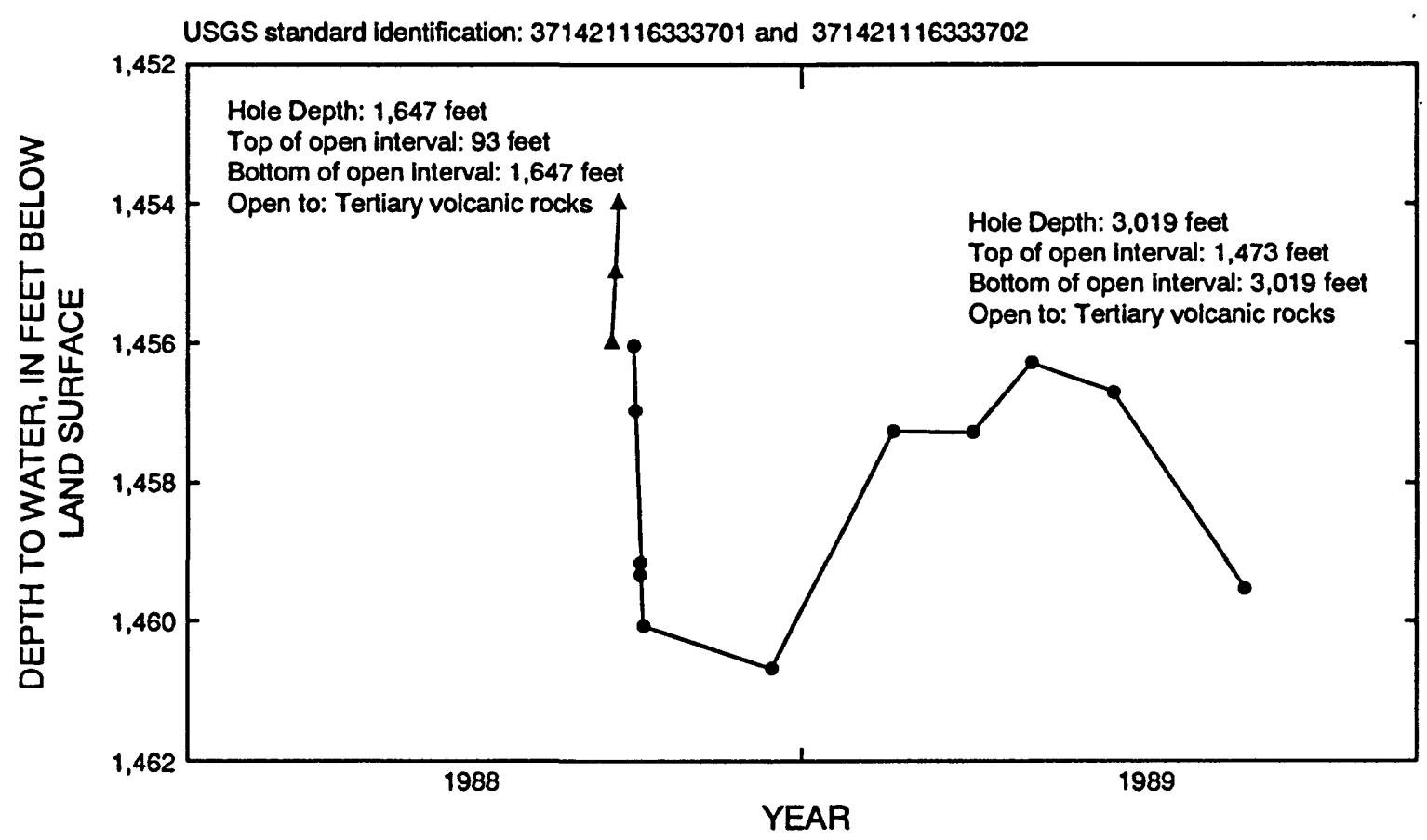

FIGURE 11.--Depth-to-water measurements at two completion depths in test hole PM-3 on Pahute Mesa.

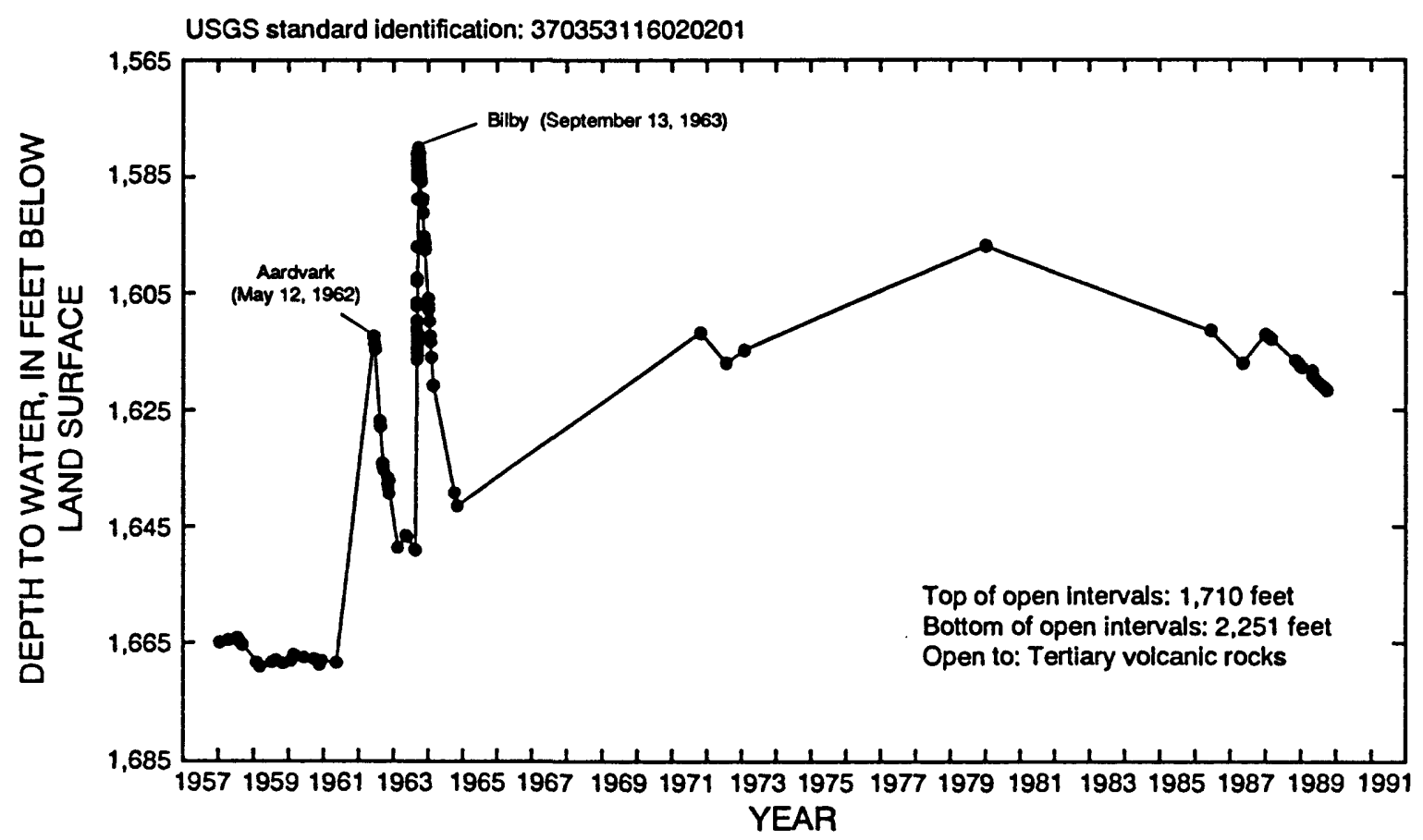

FIGURE 12.--Depth-to-water measurements in well TW-7 in Yucca Flat.

Names and dates are indicated for nearby weapons tests. 


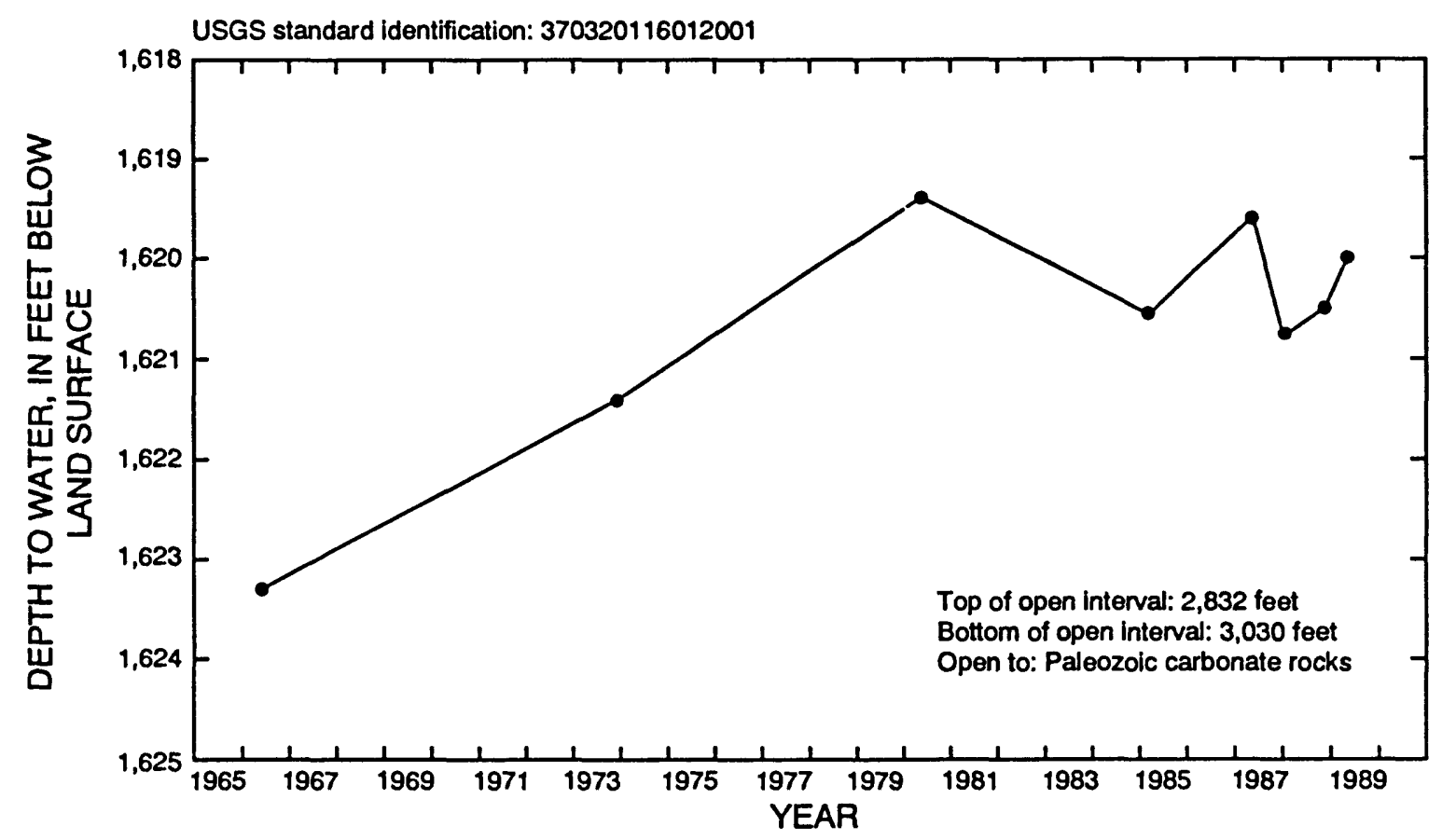

FIGURE 13.--Depth-to-water measurements in test hole U-3en 5 in Yucca Flat.

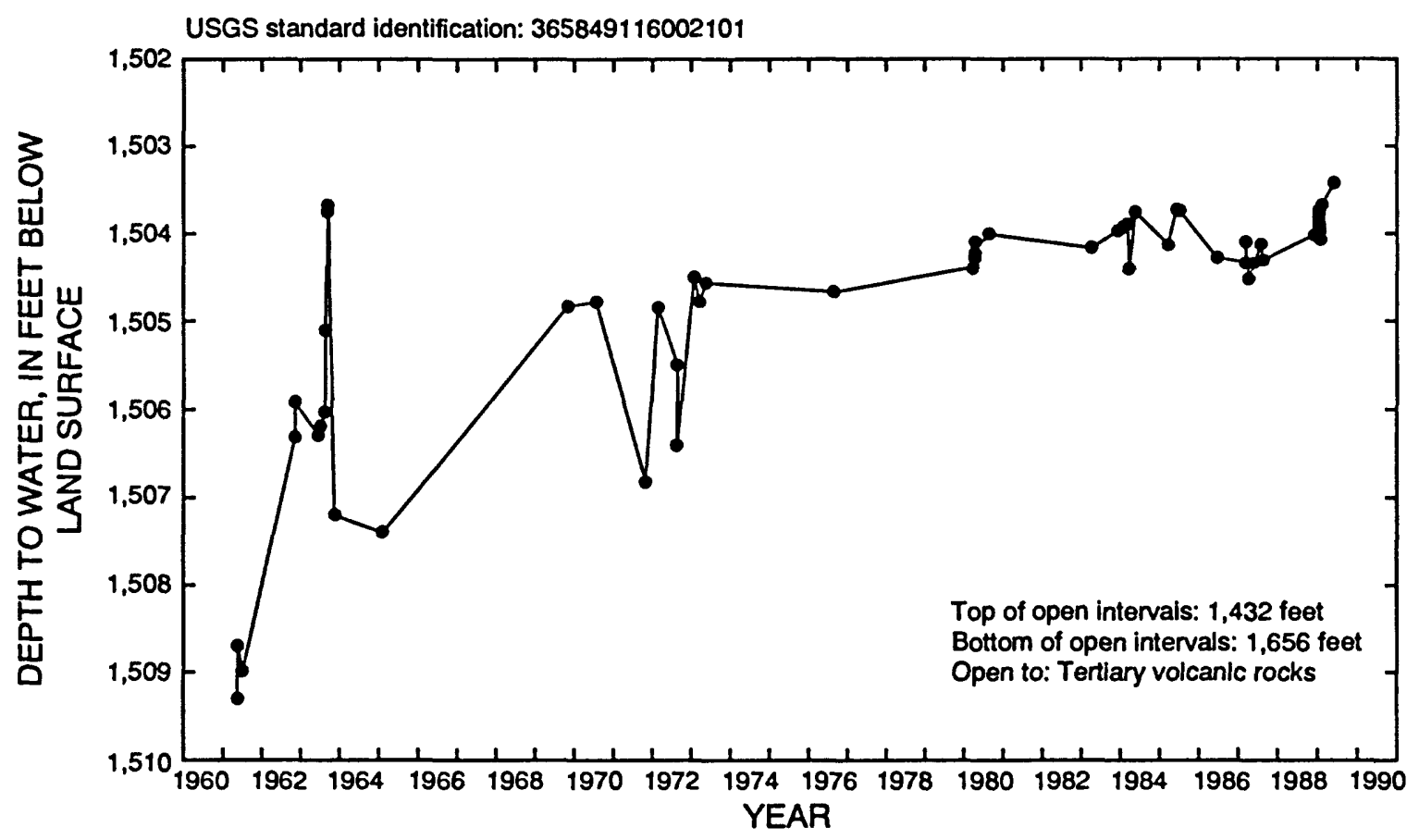

FIGURE 14.--Depth-to-water measurements in test hole TW-B in Yucca Flat. 


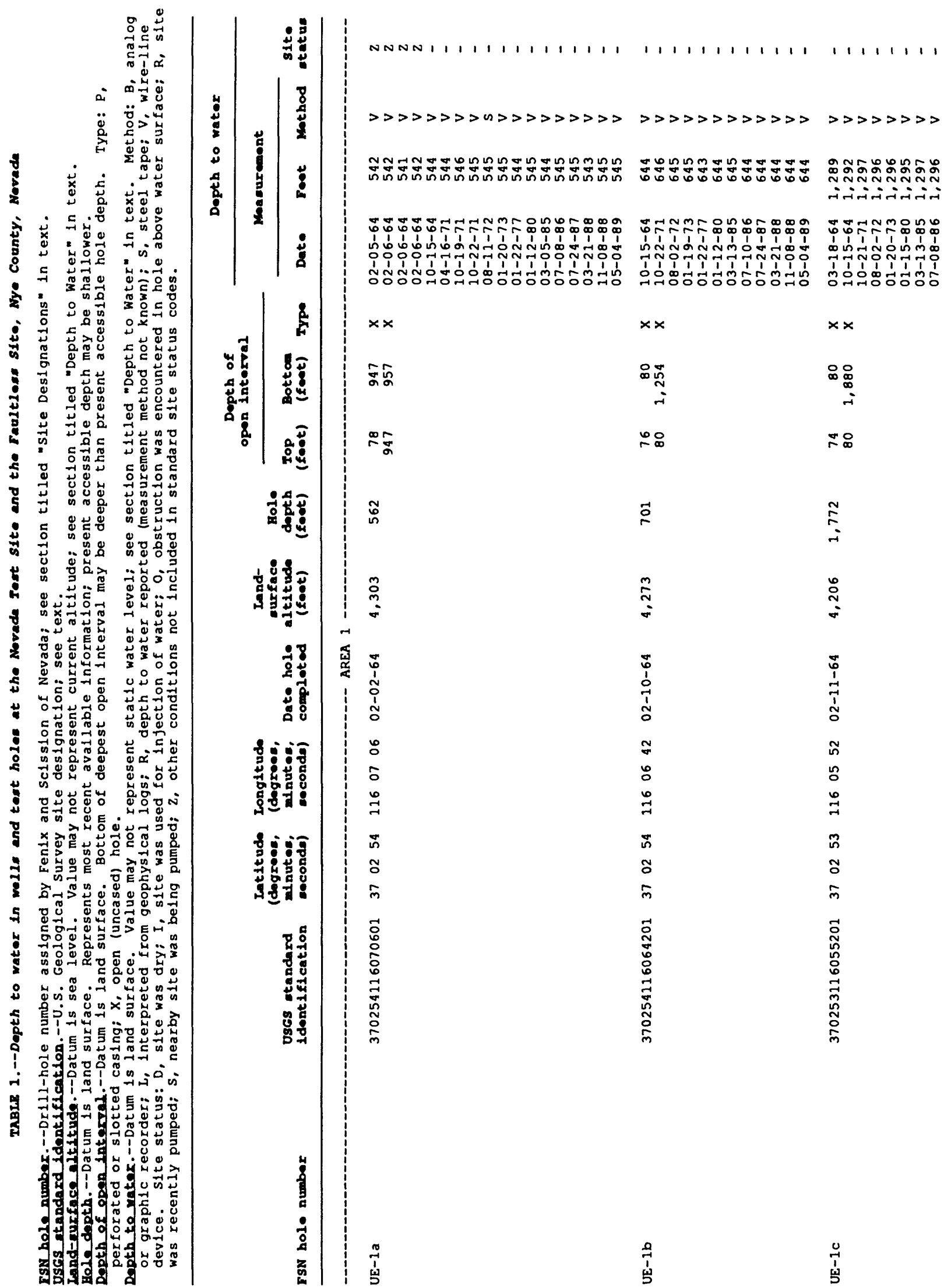




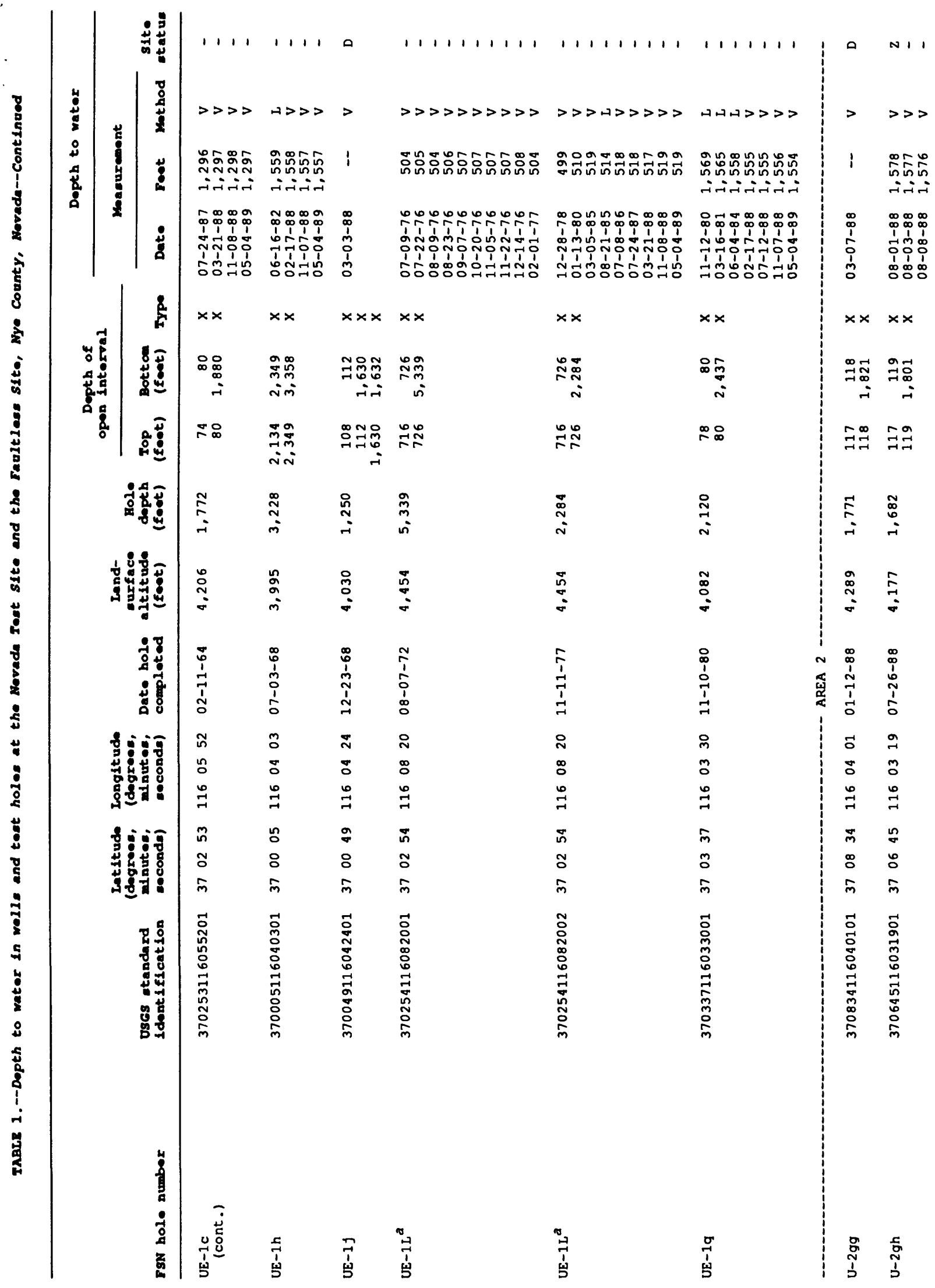




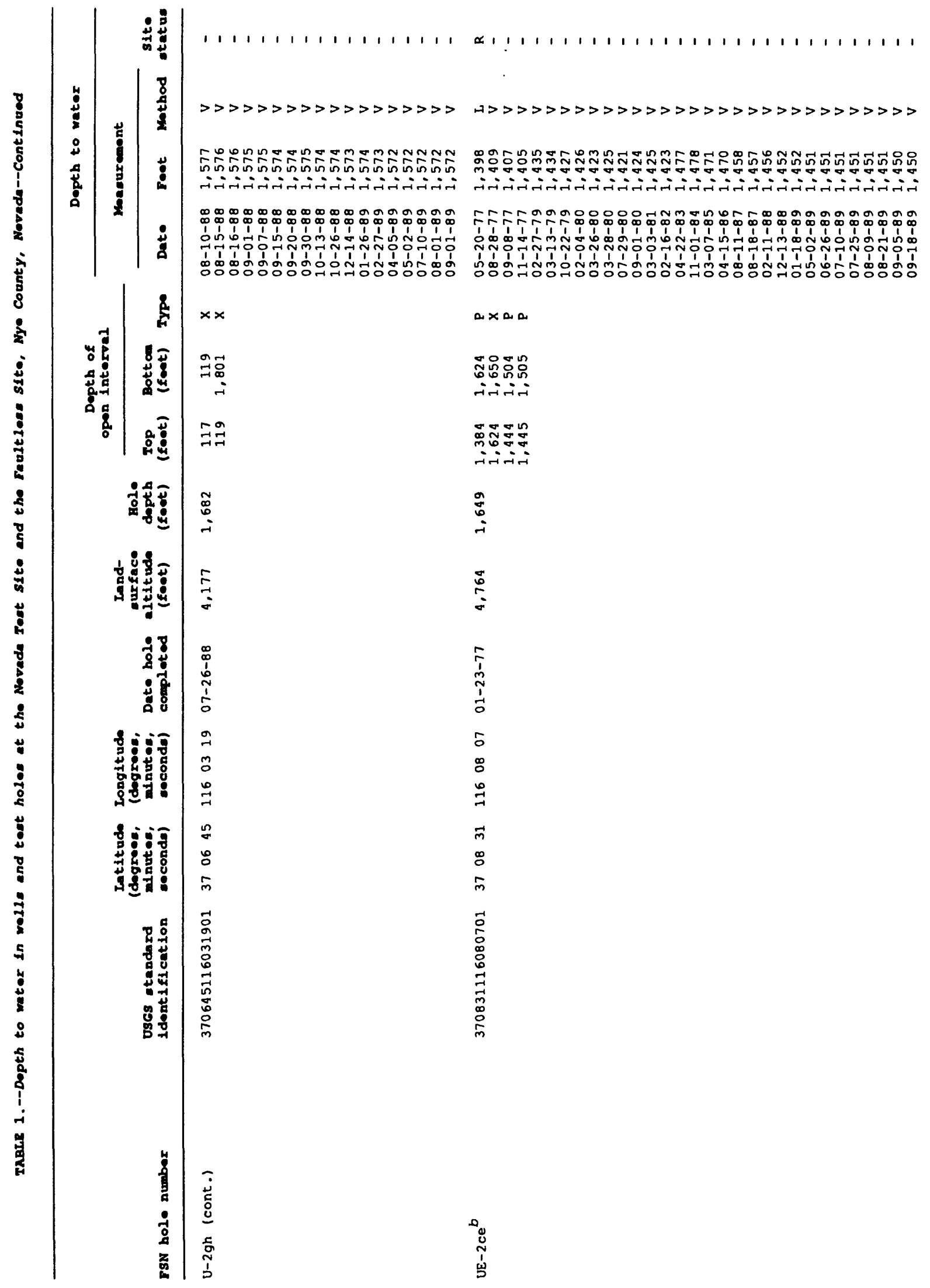

$-19$ 


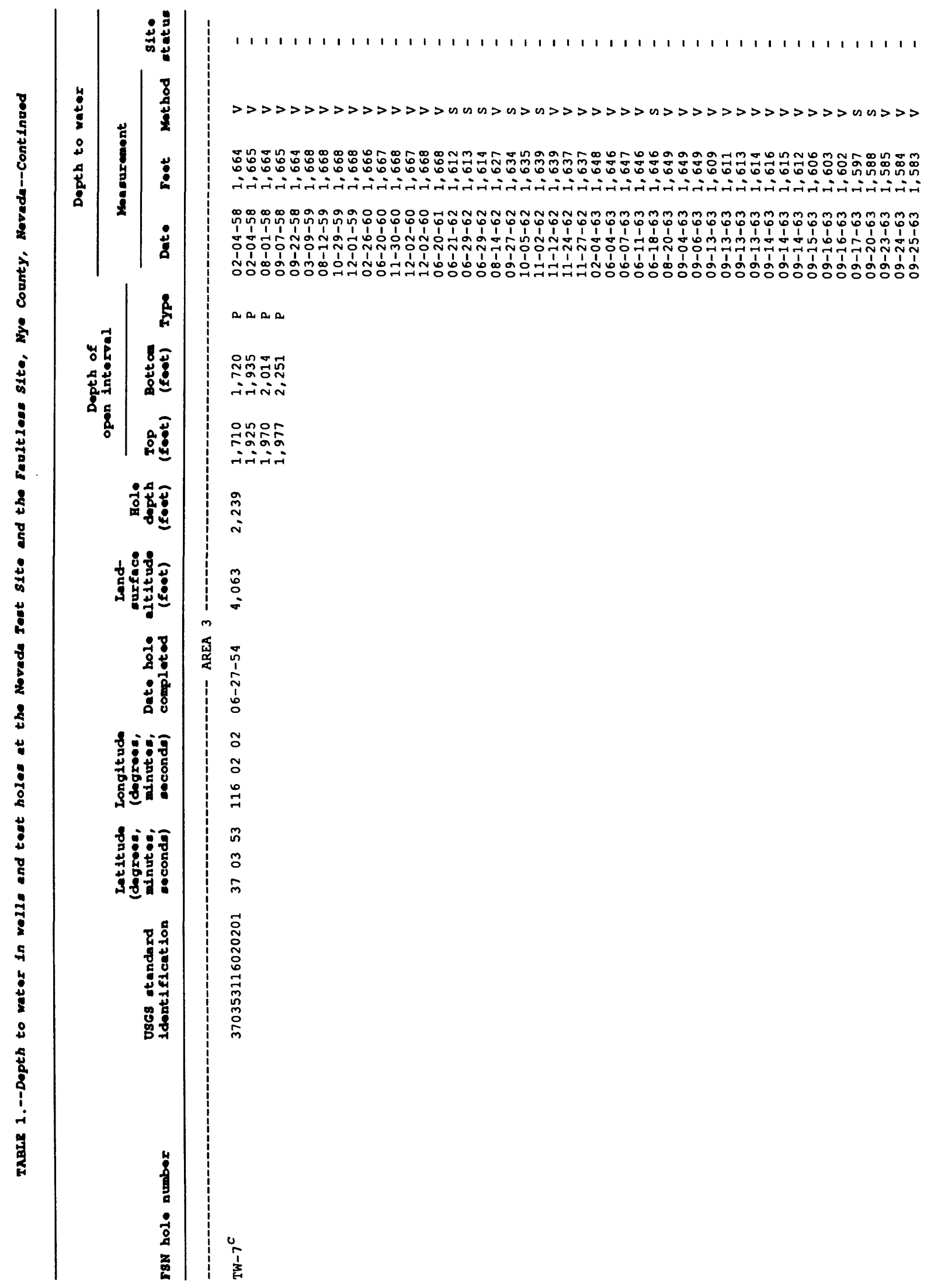




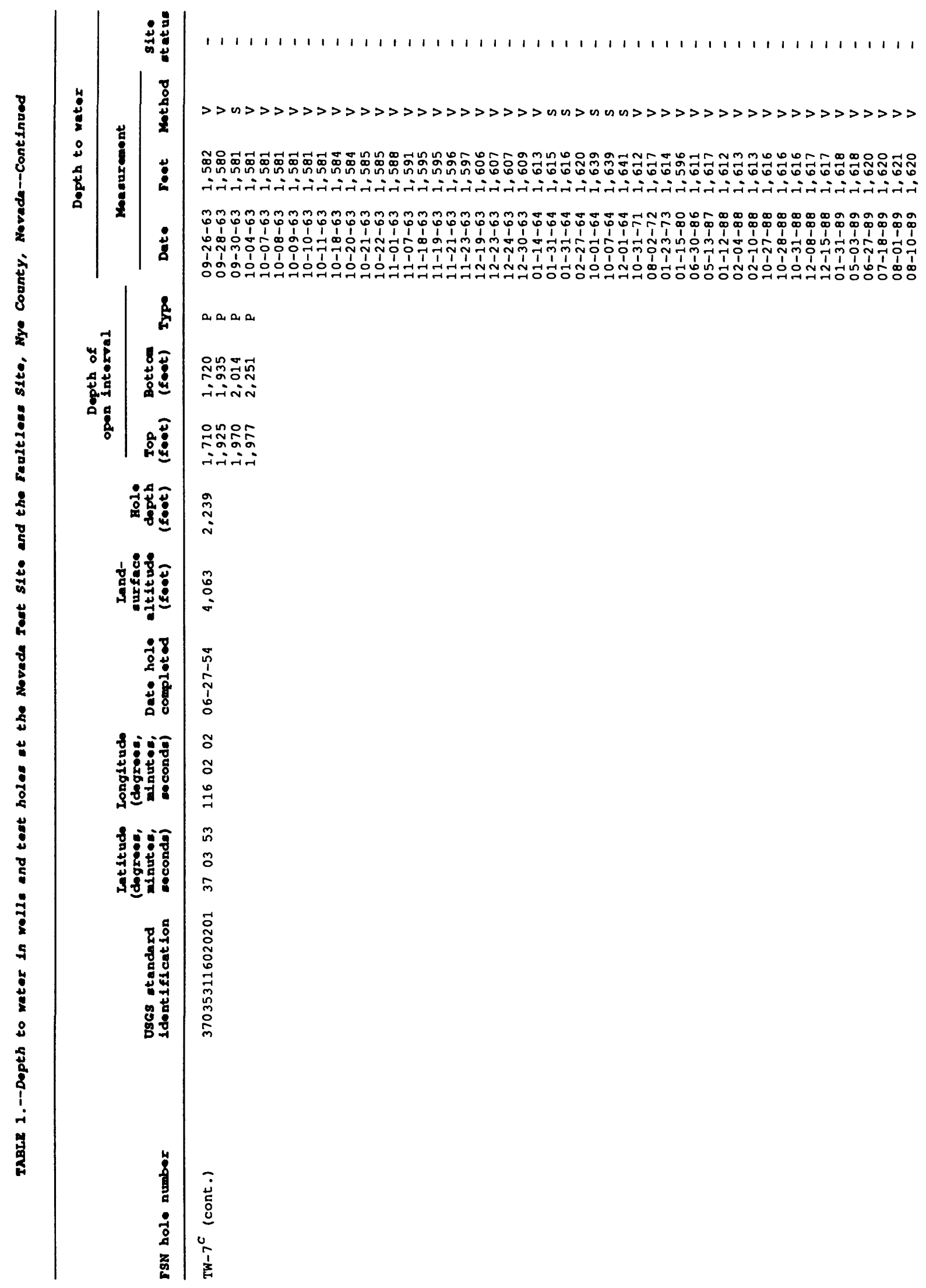




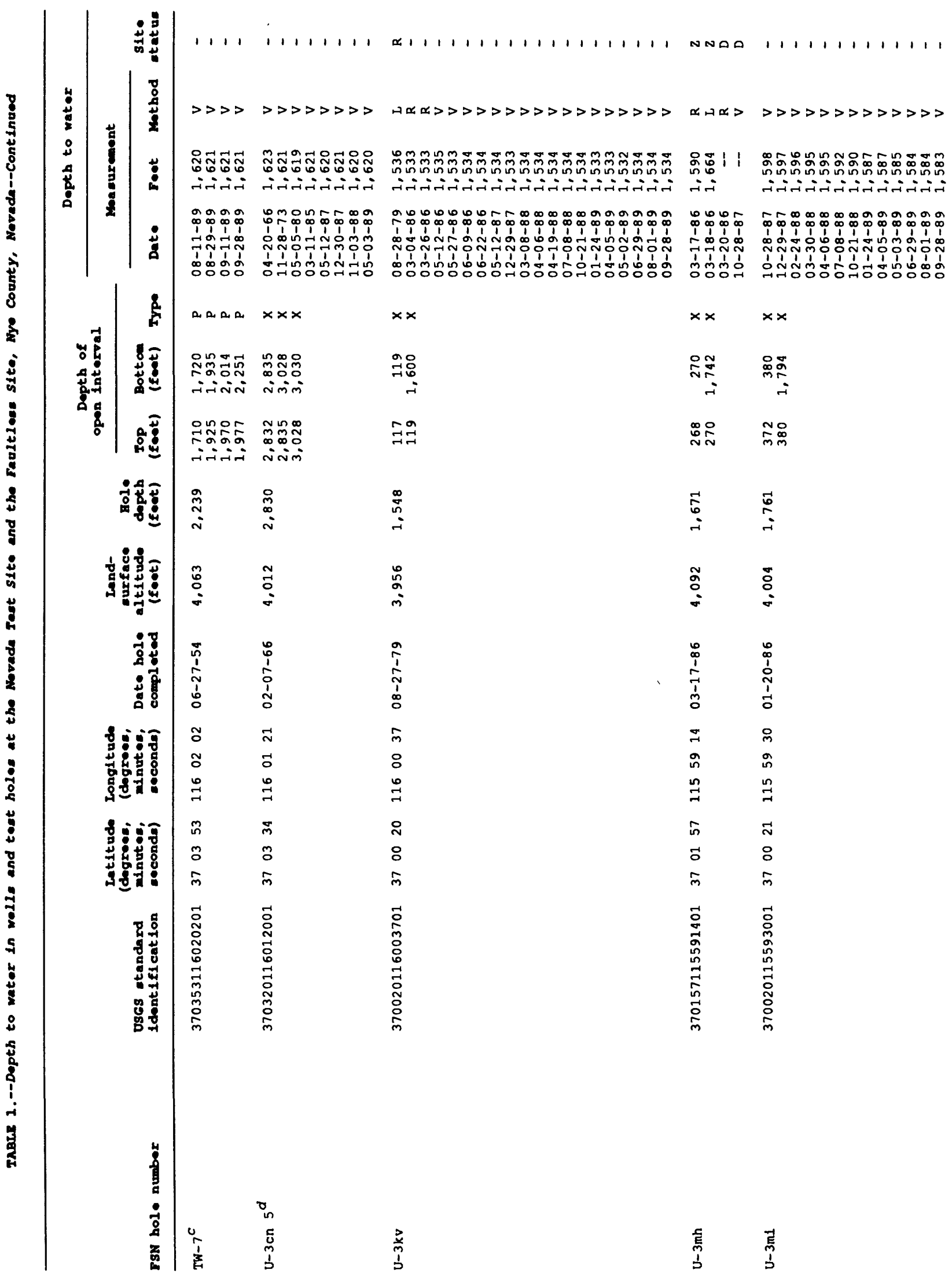




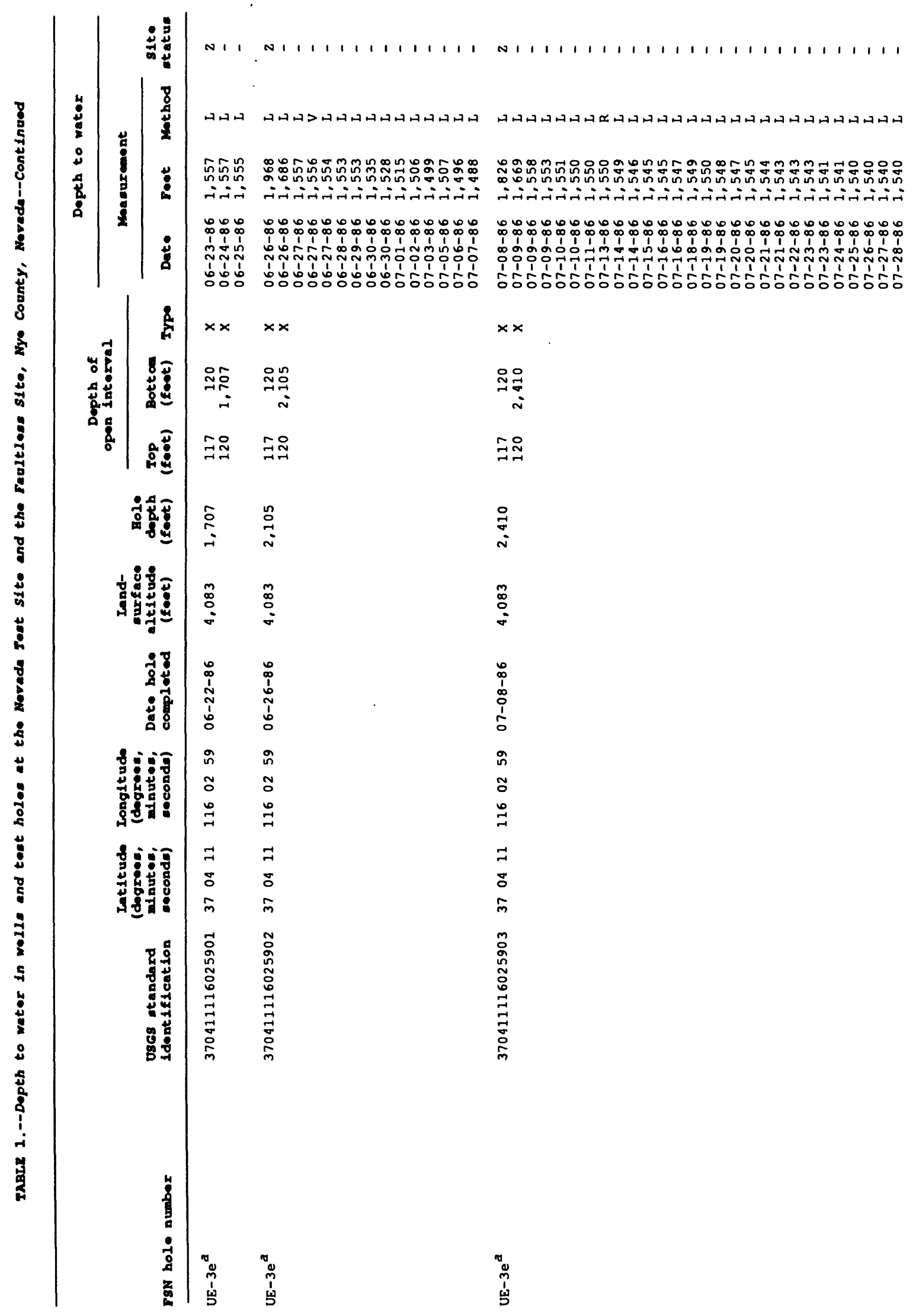




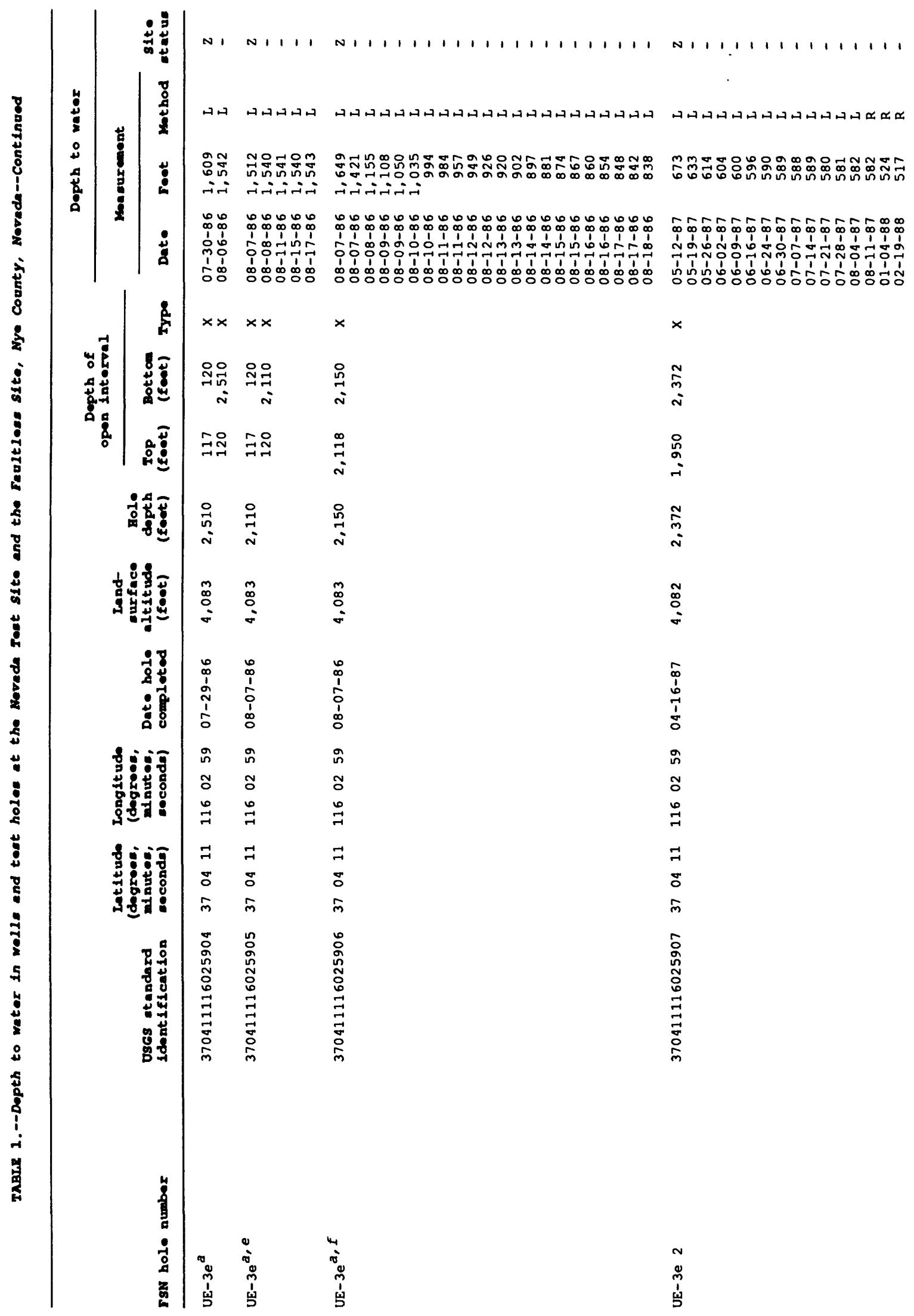




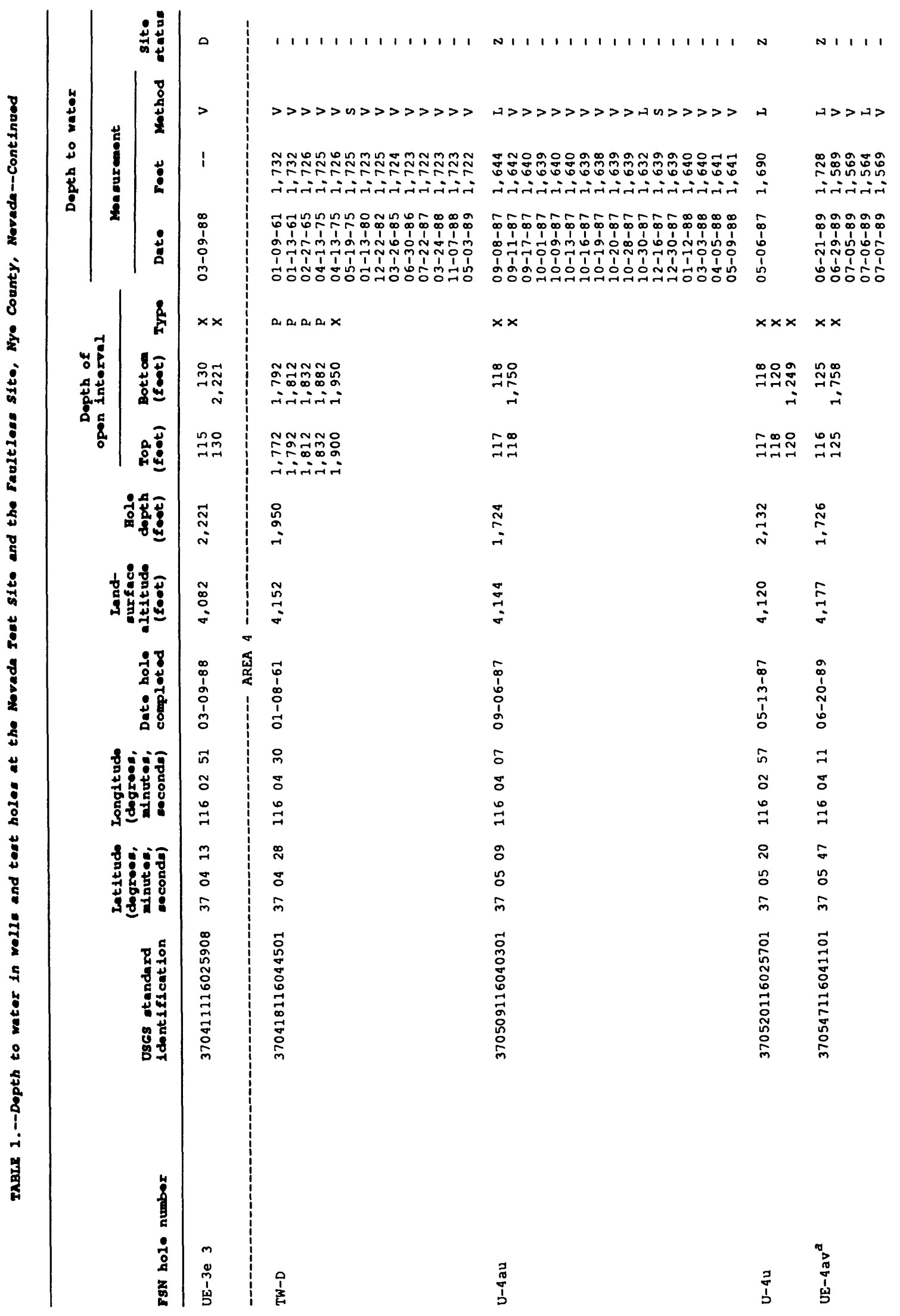




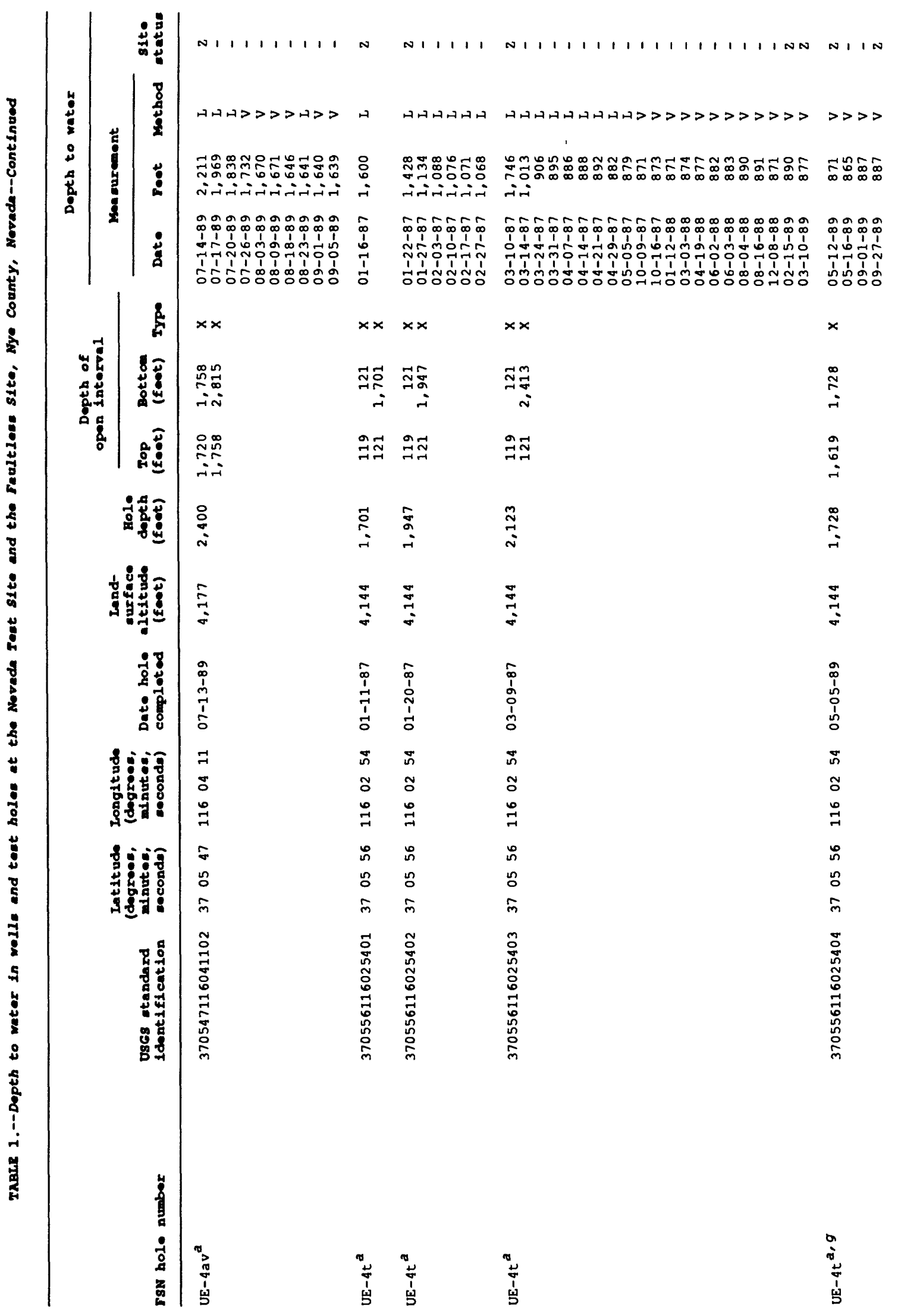




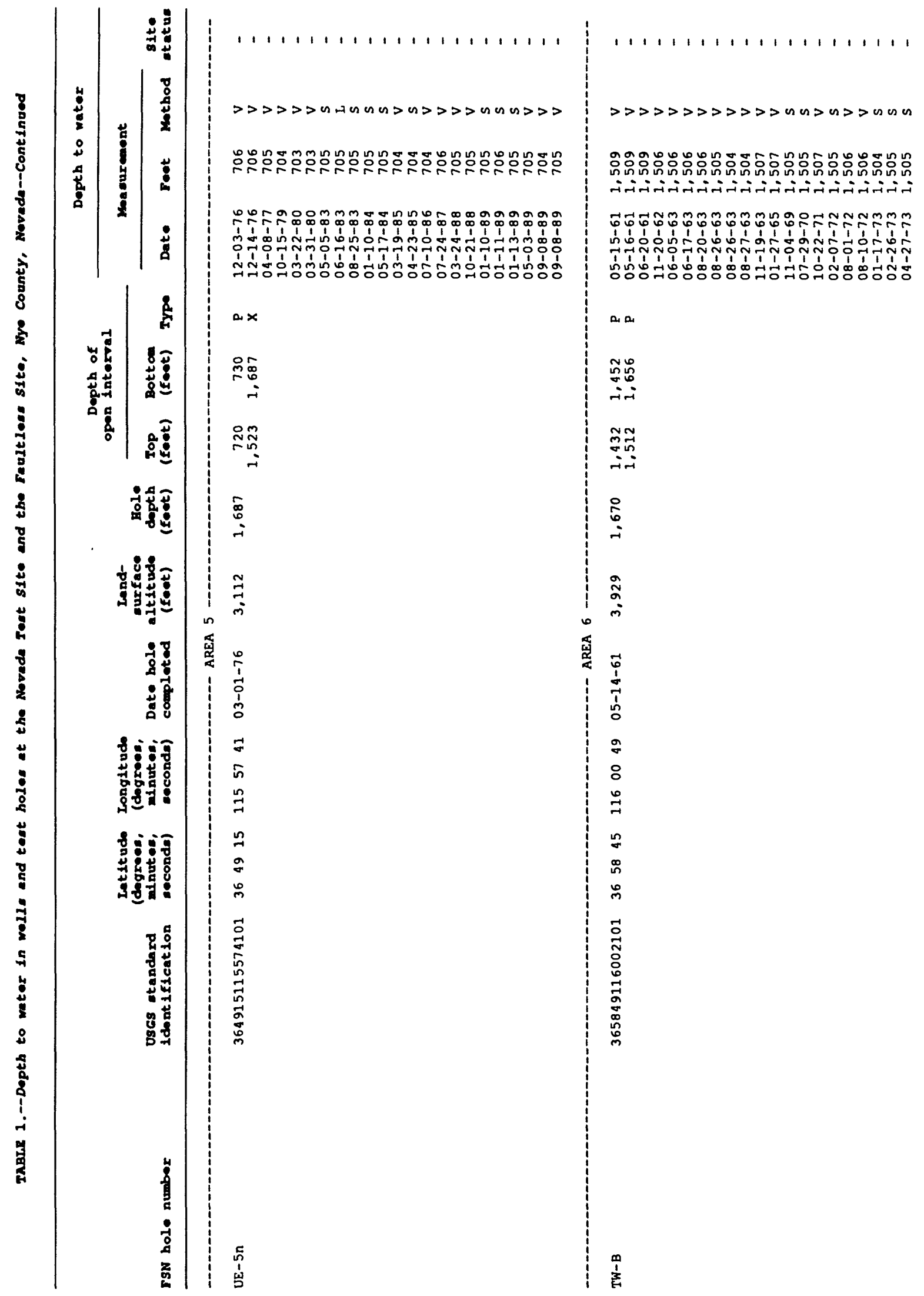




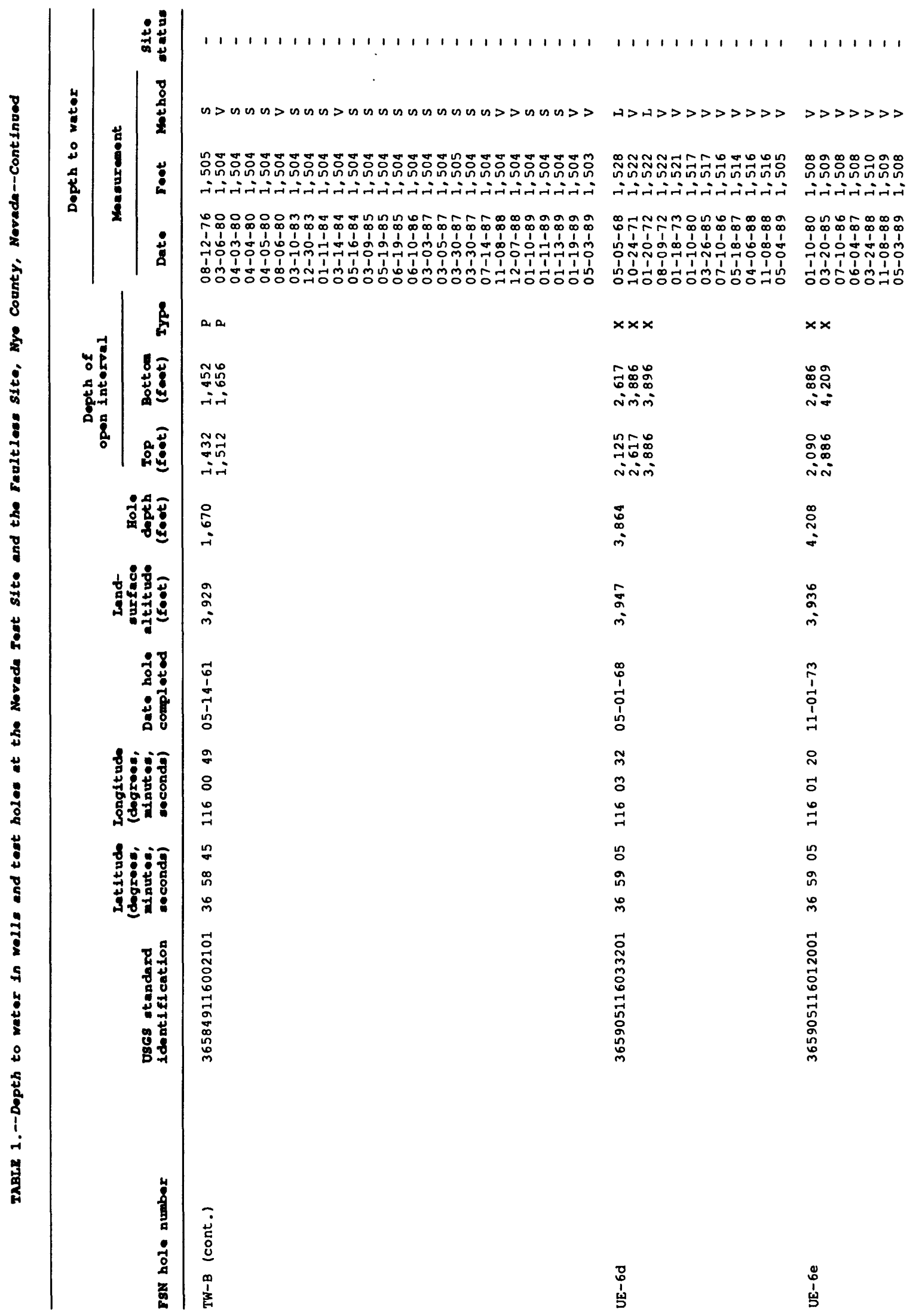




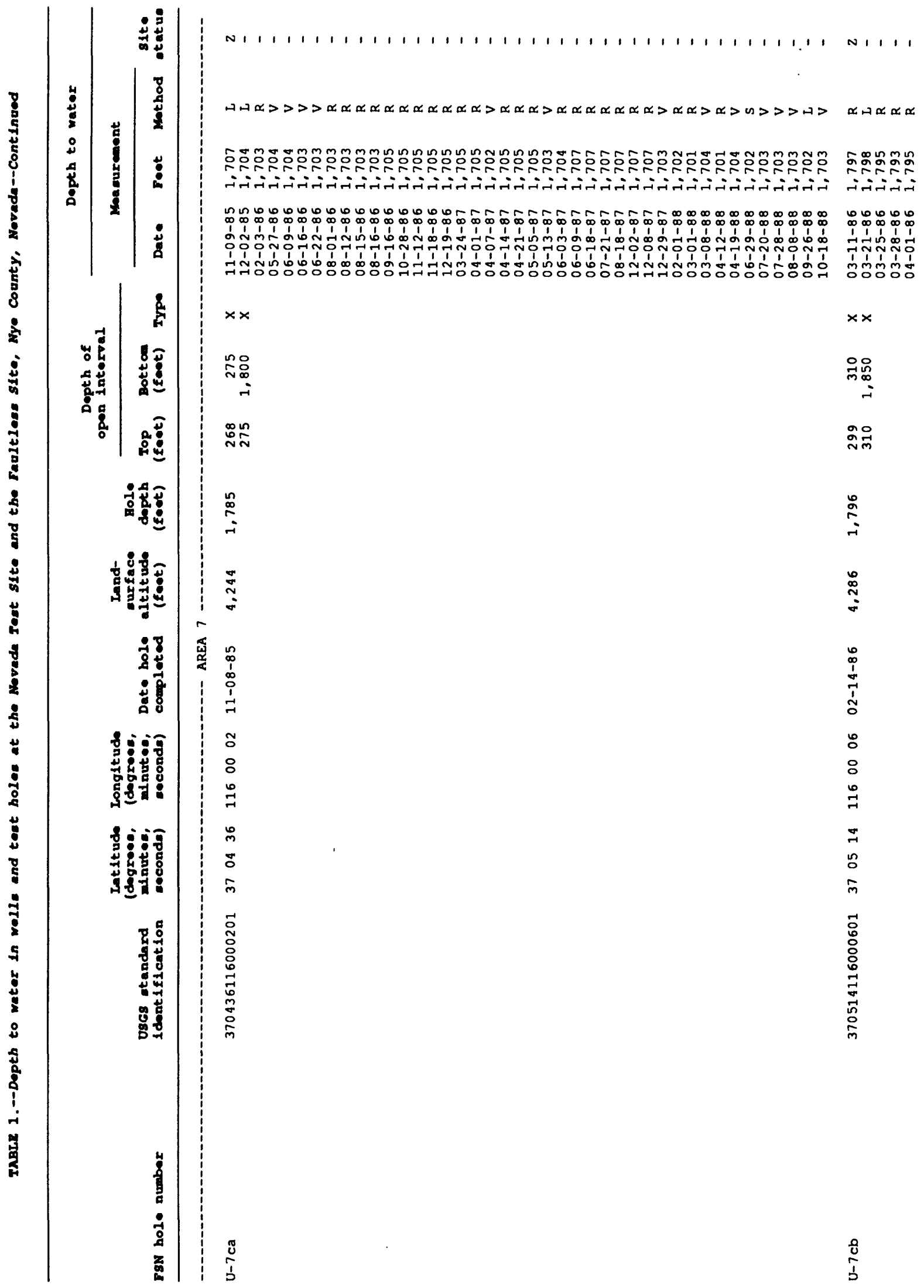




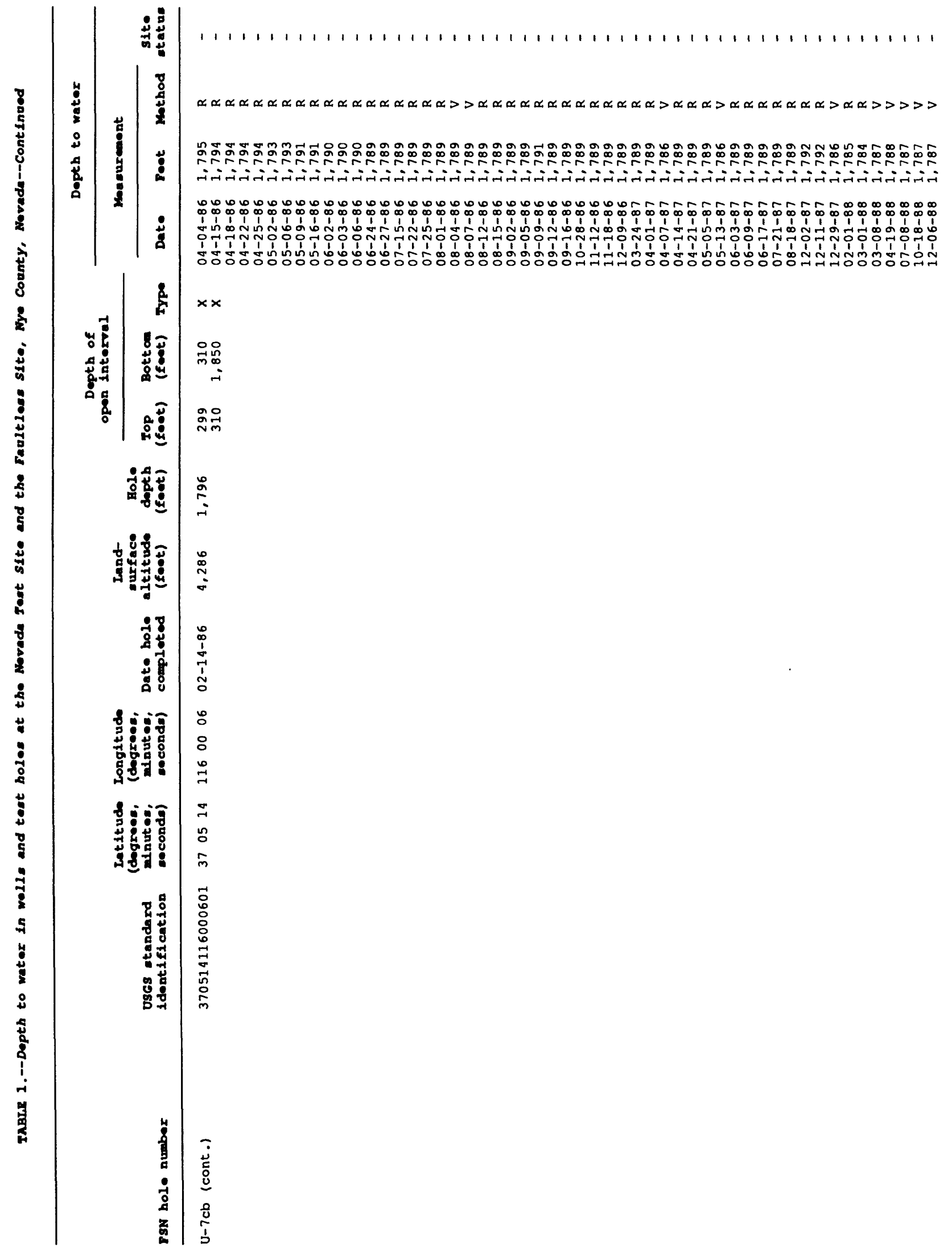




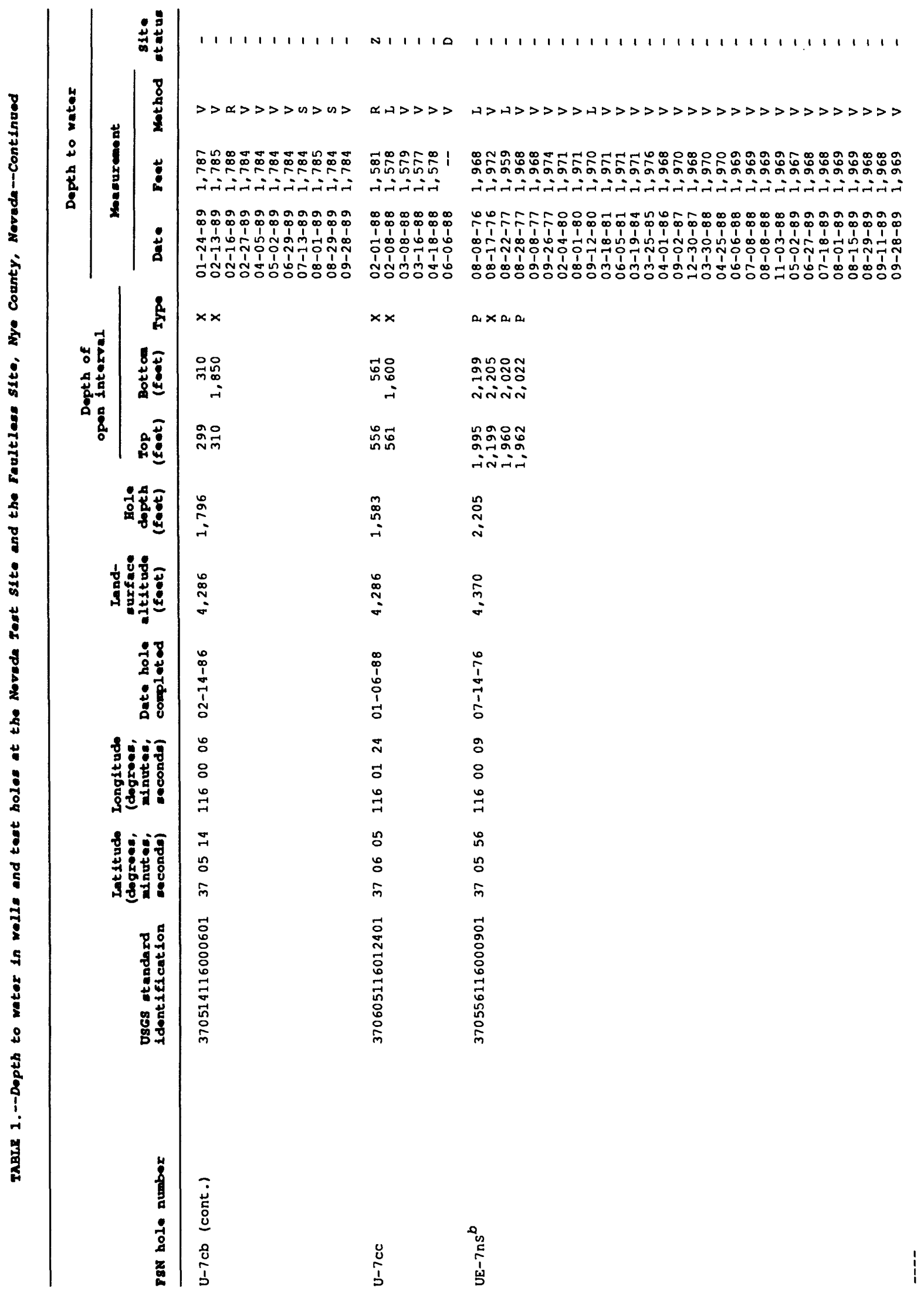




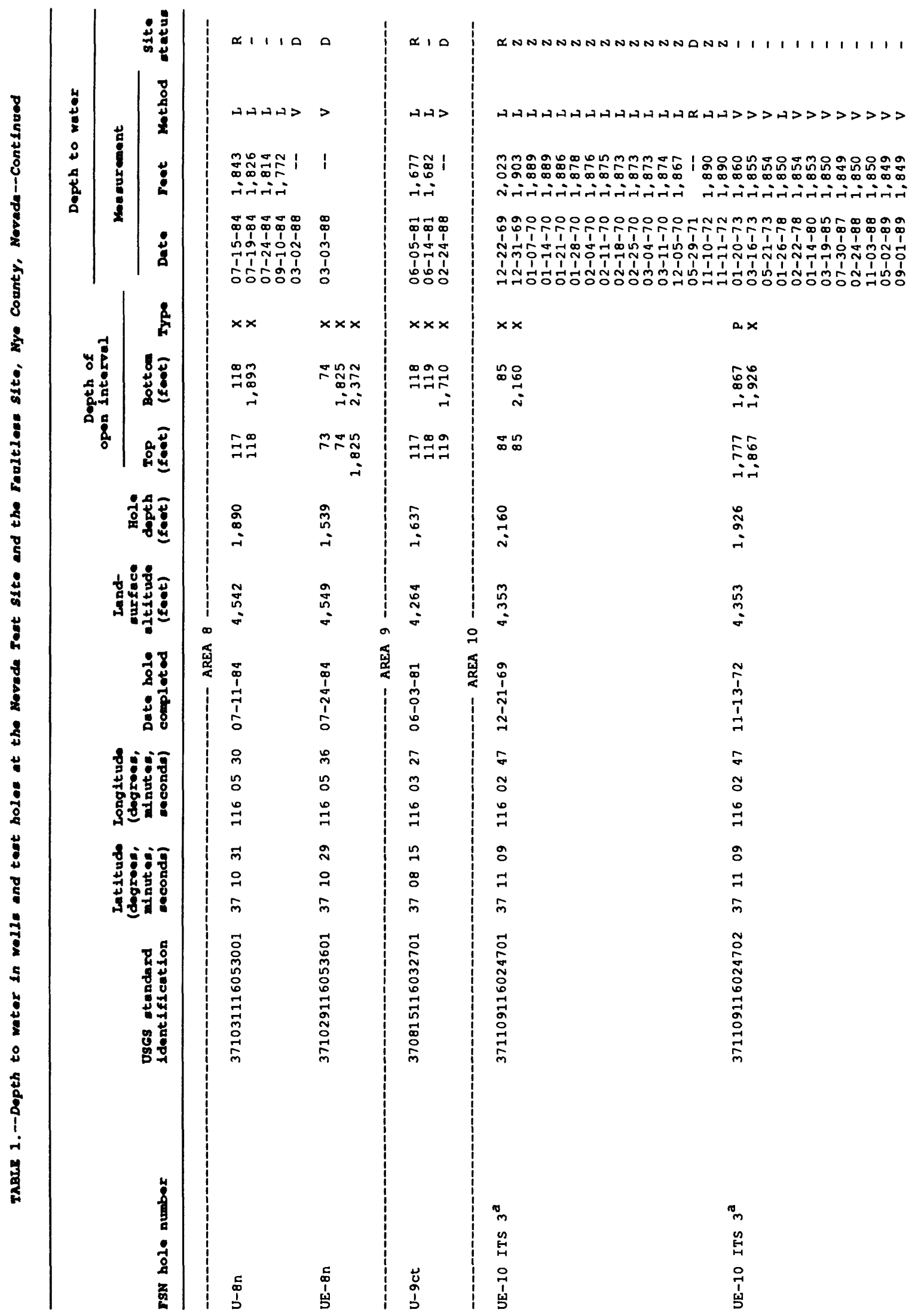




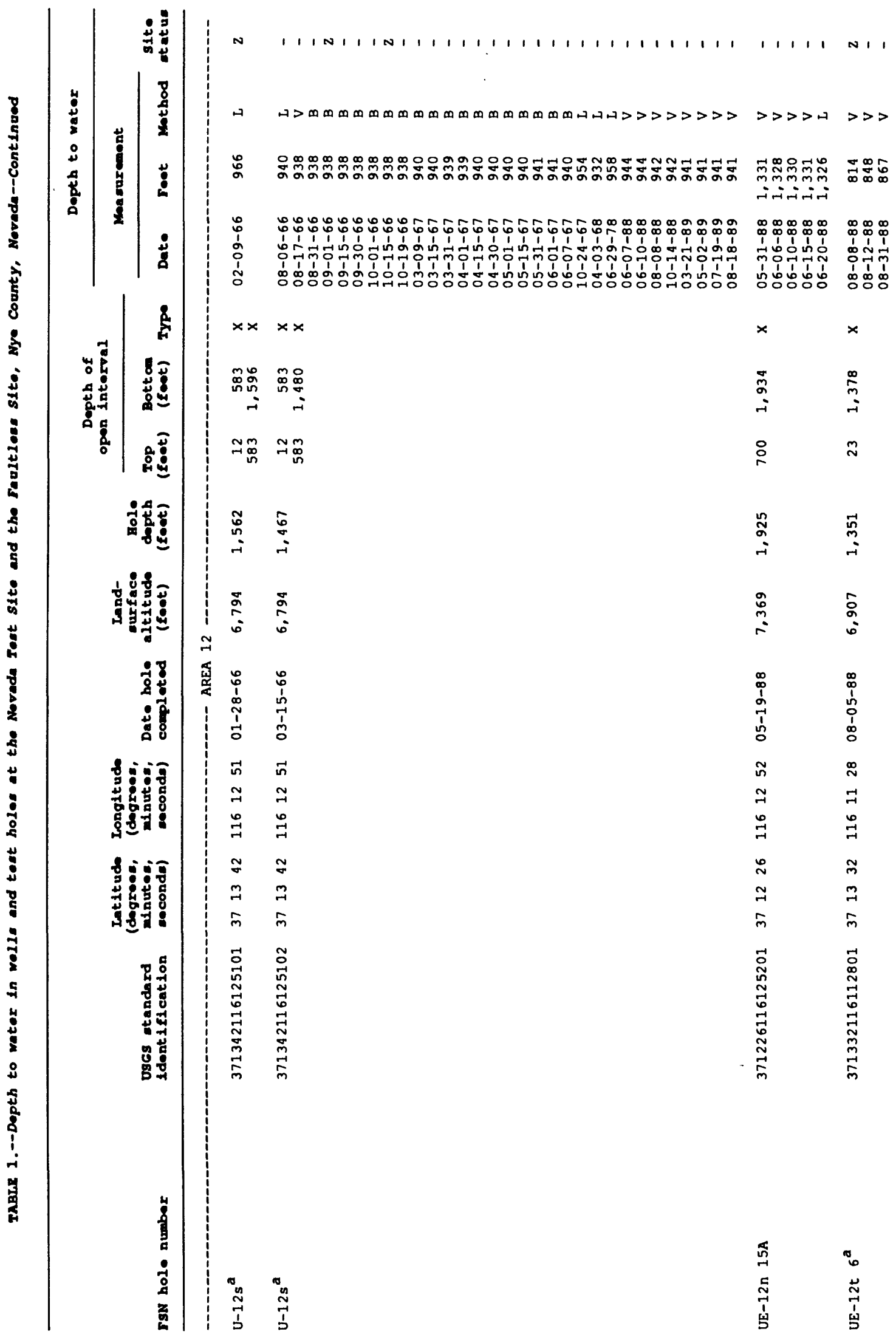




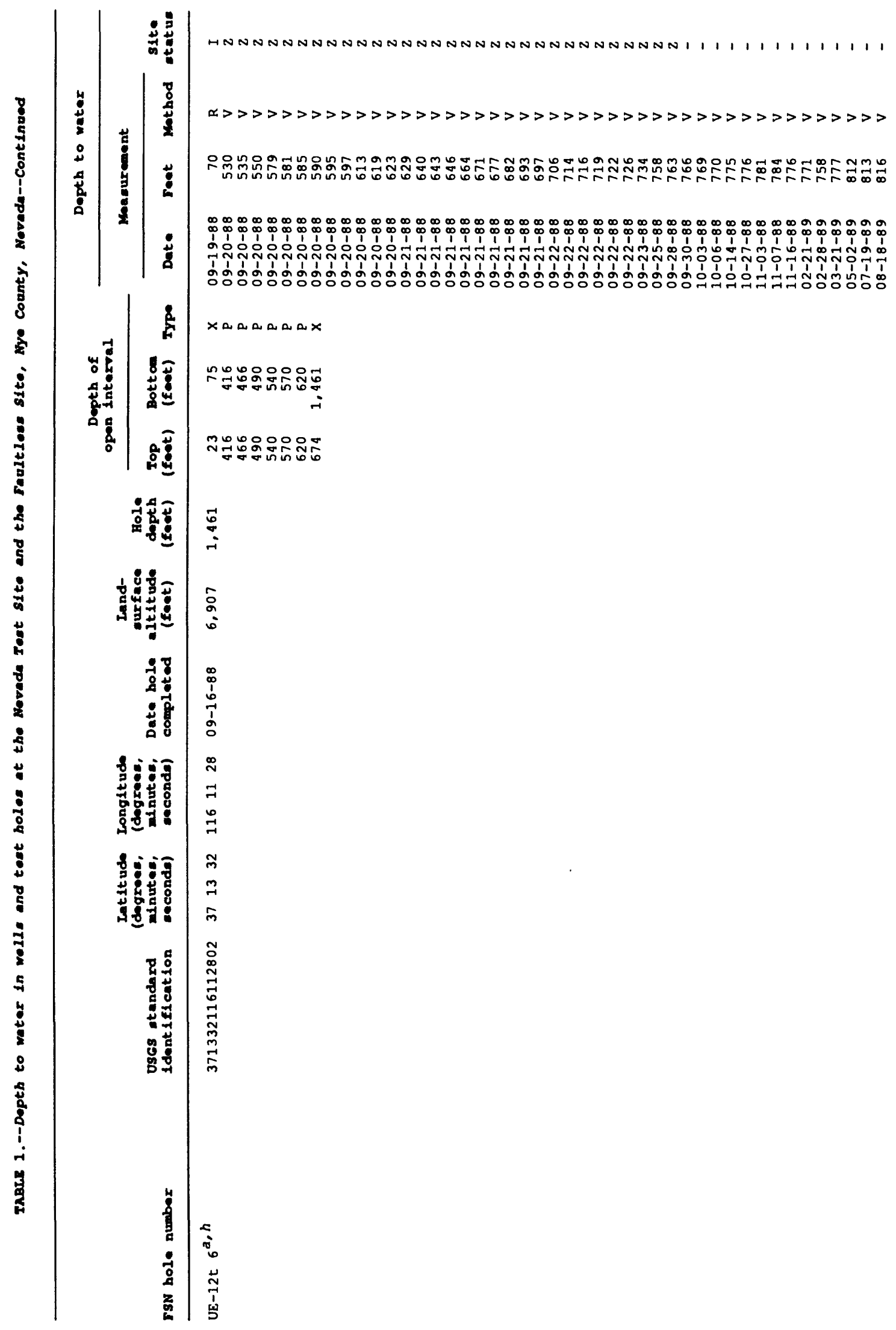




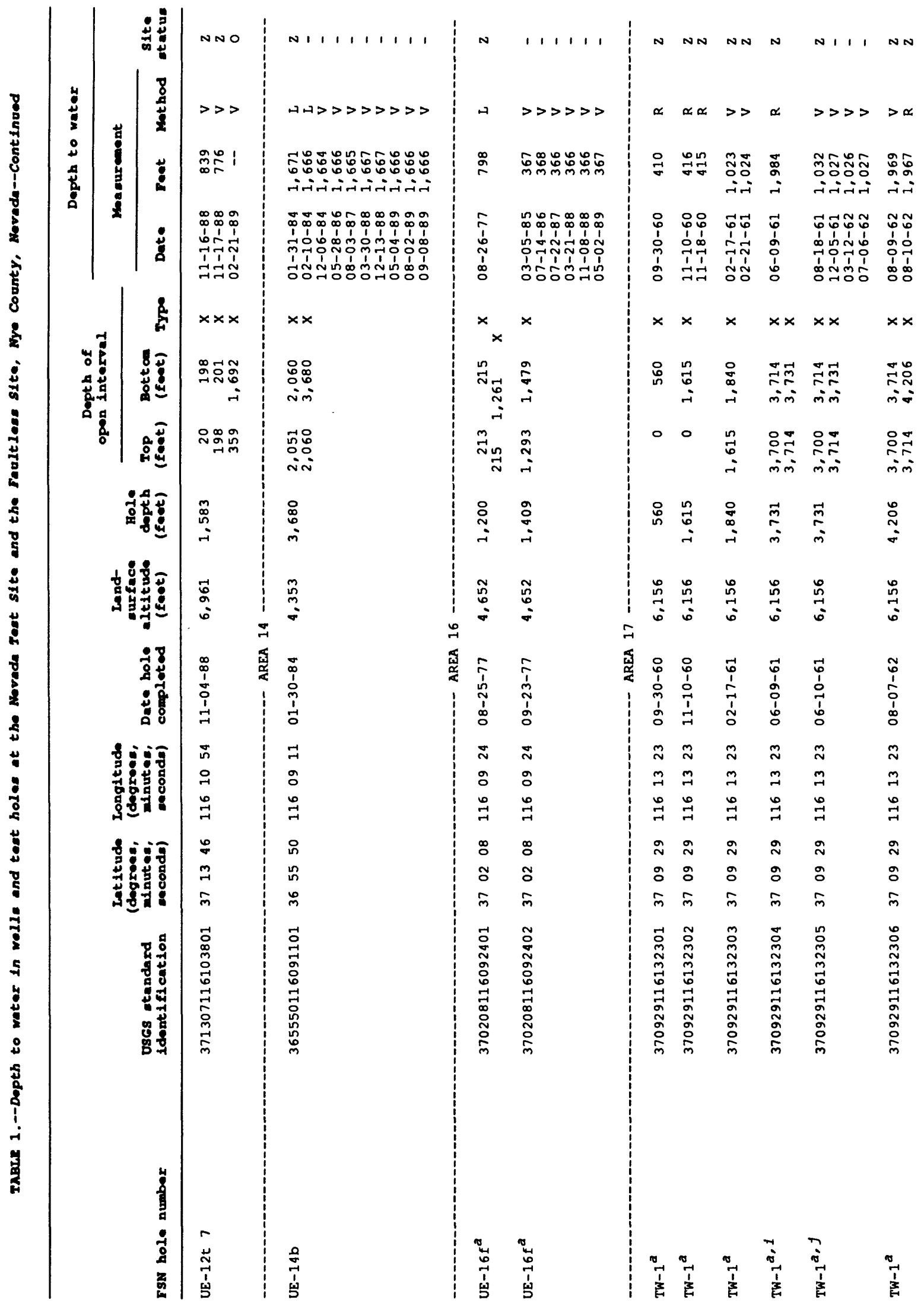




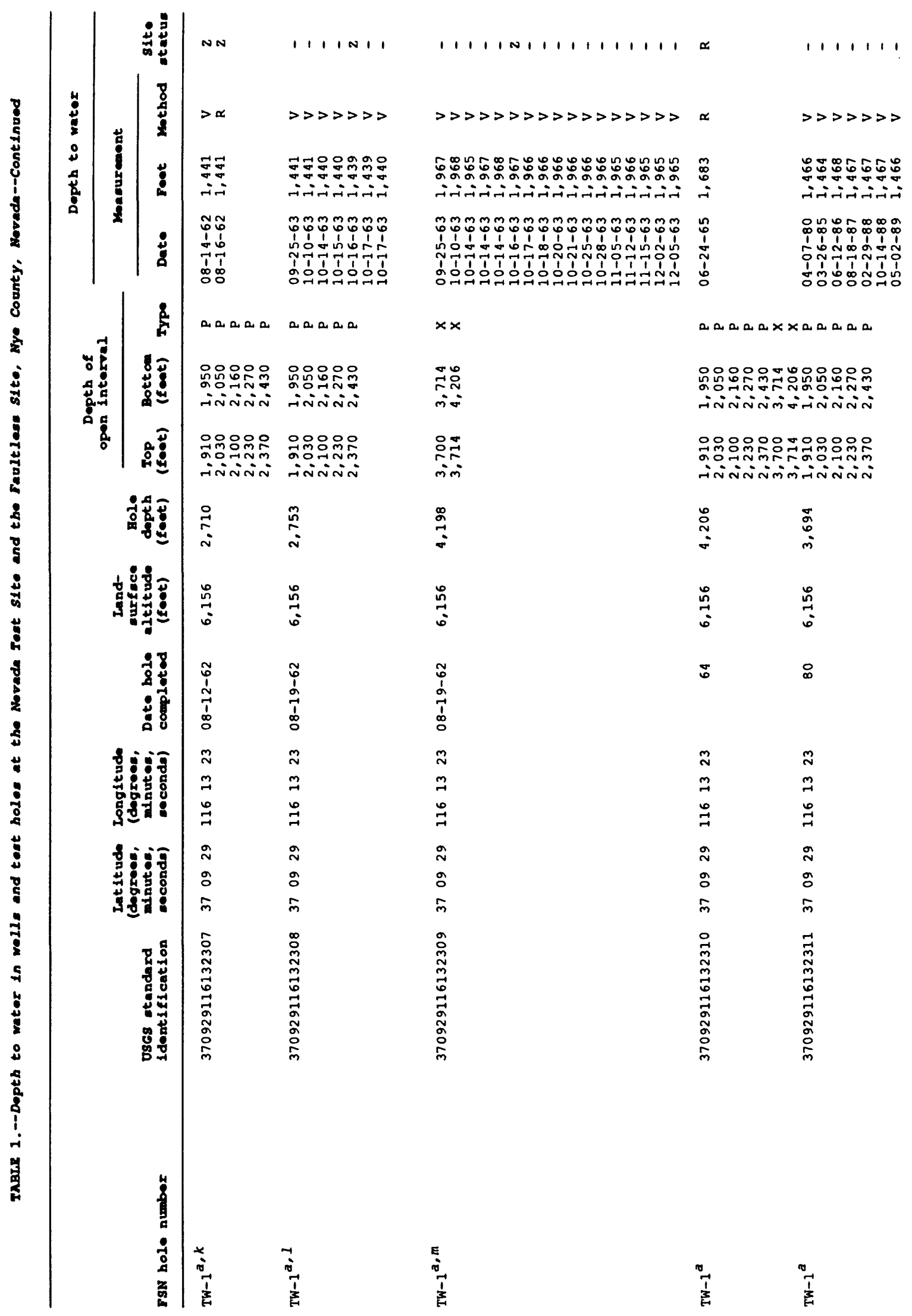




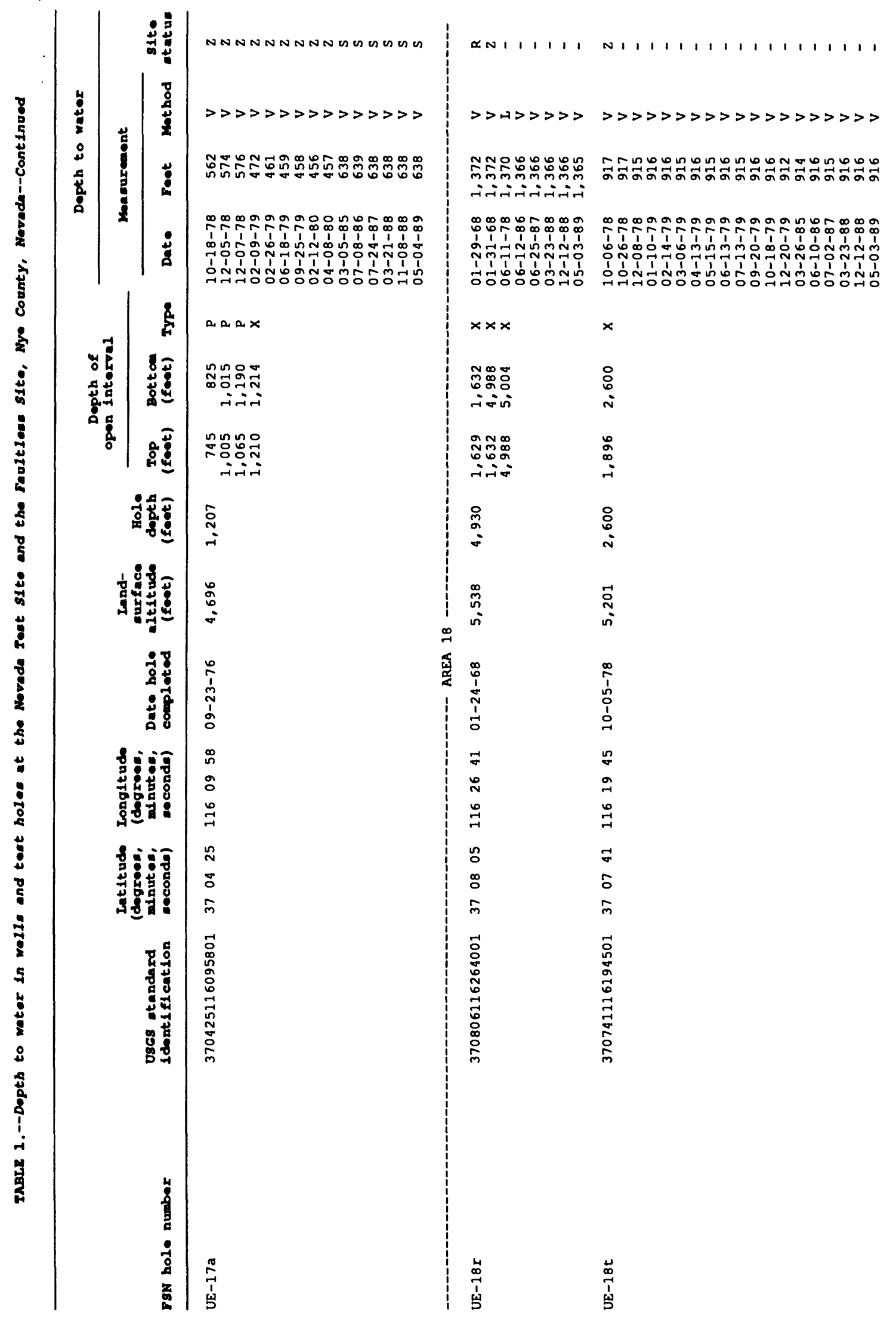




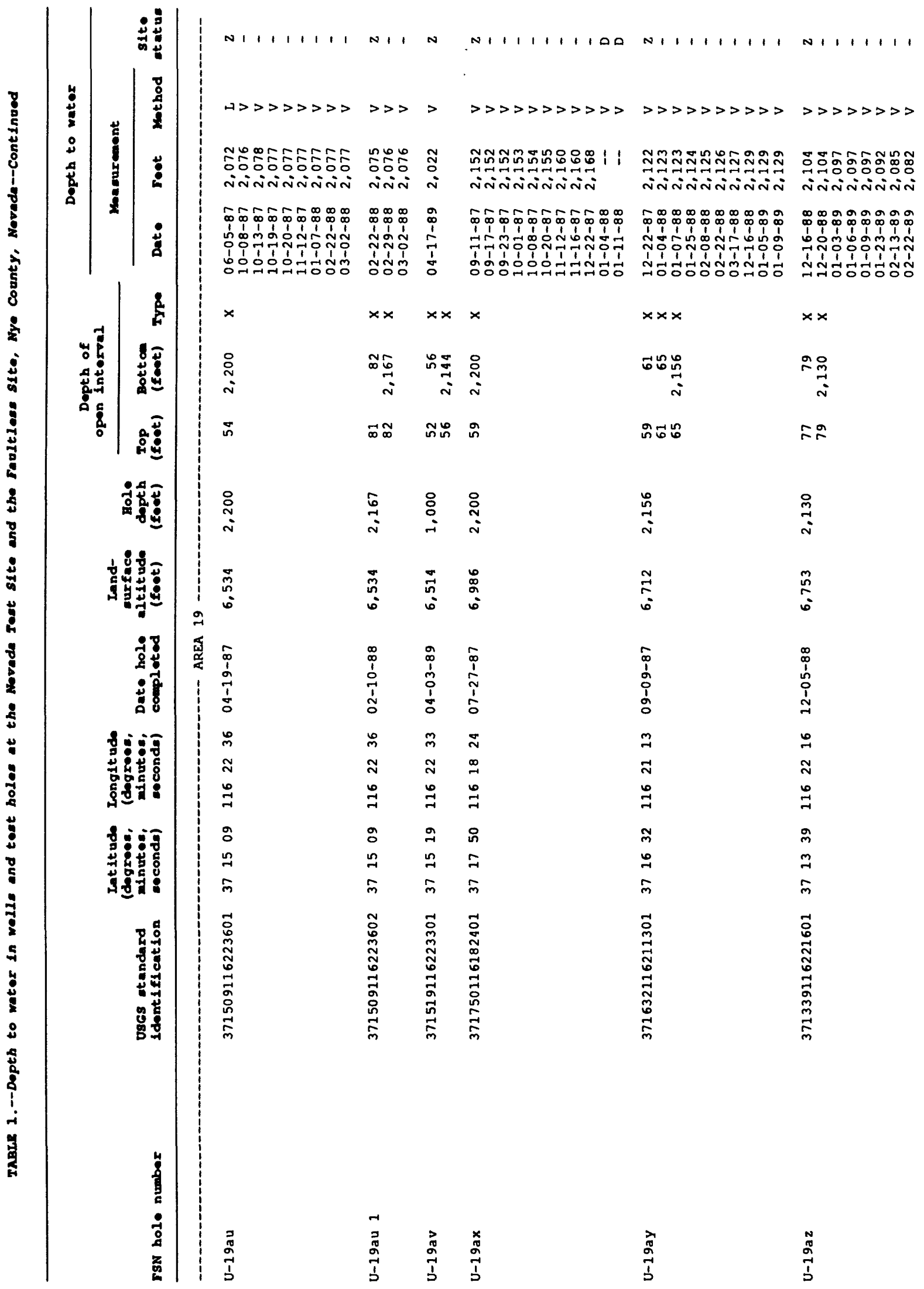




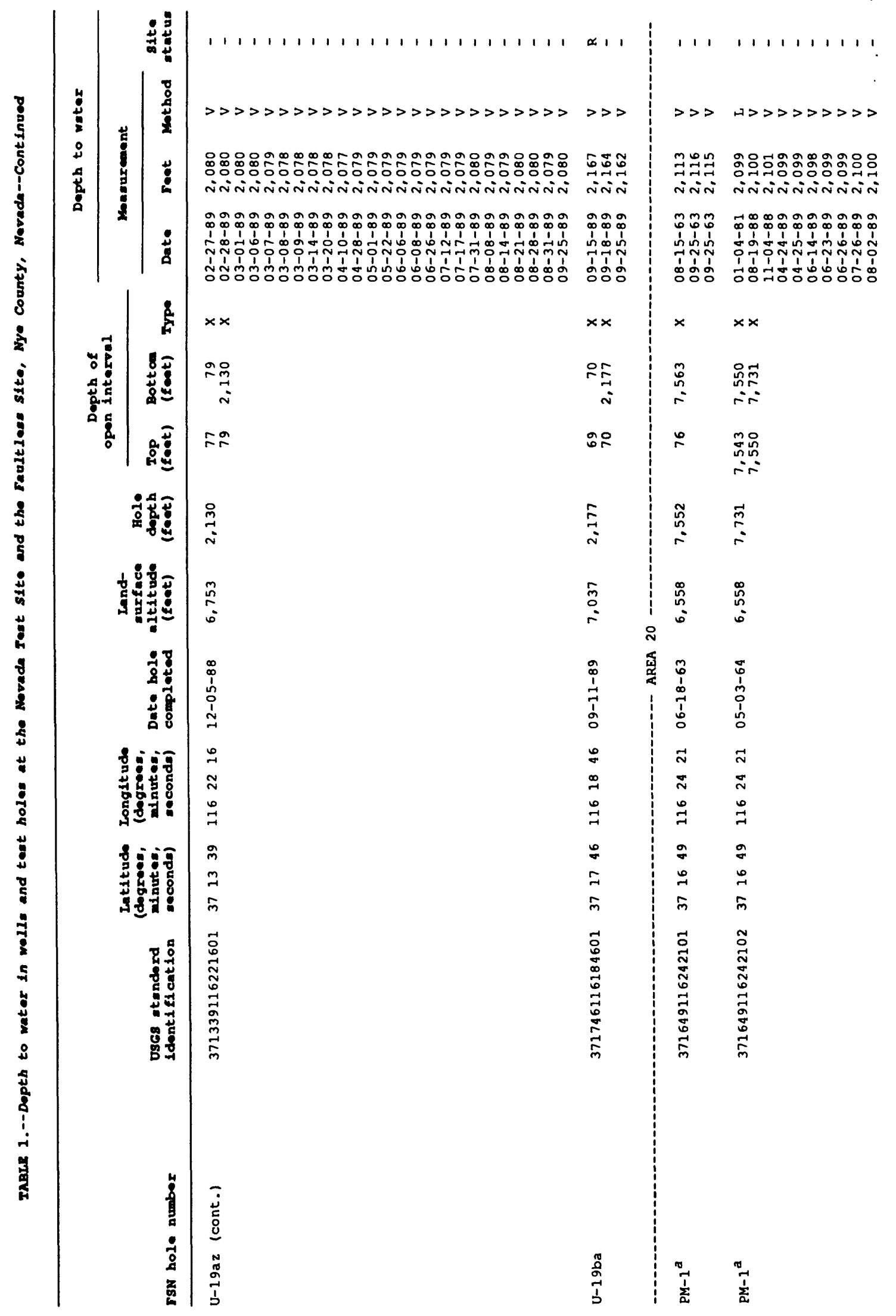




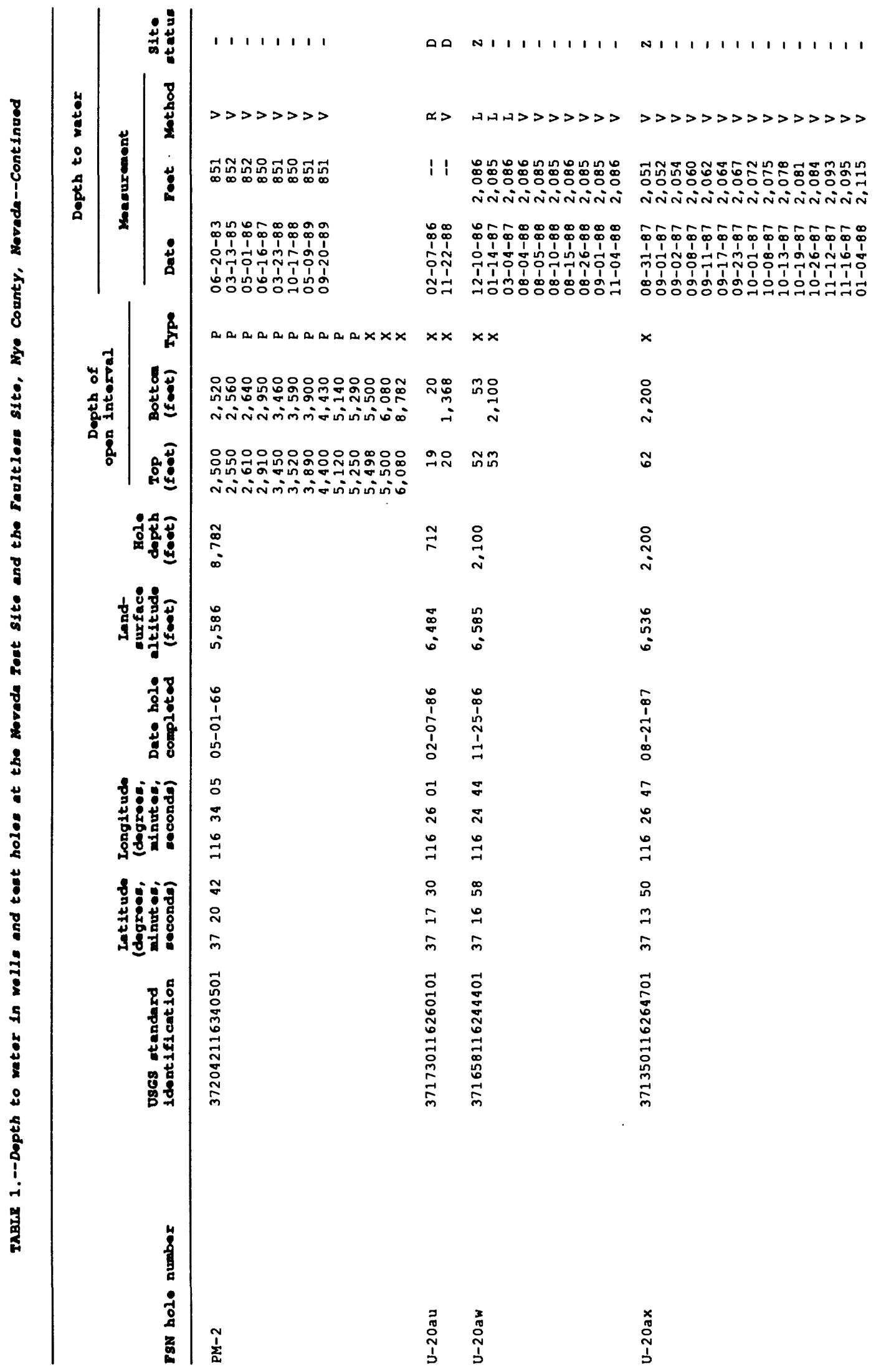




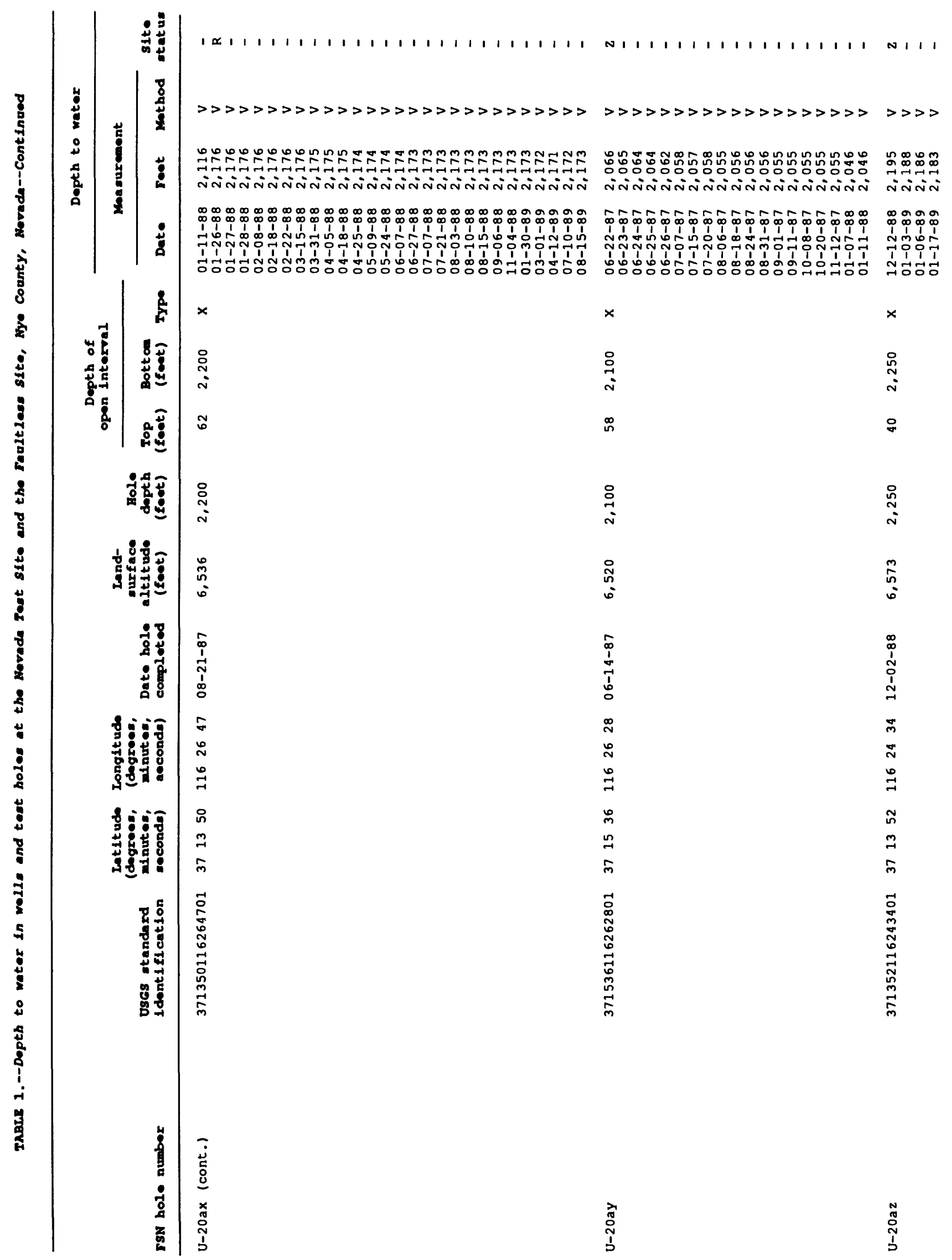




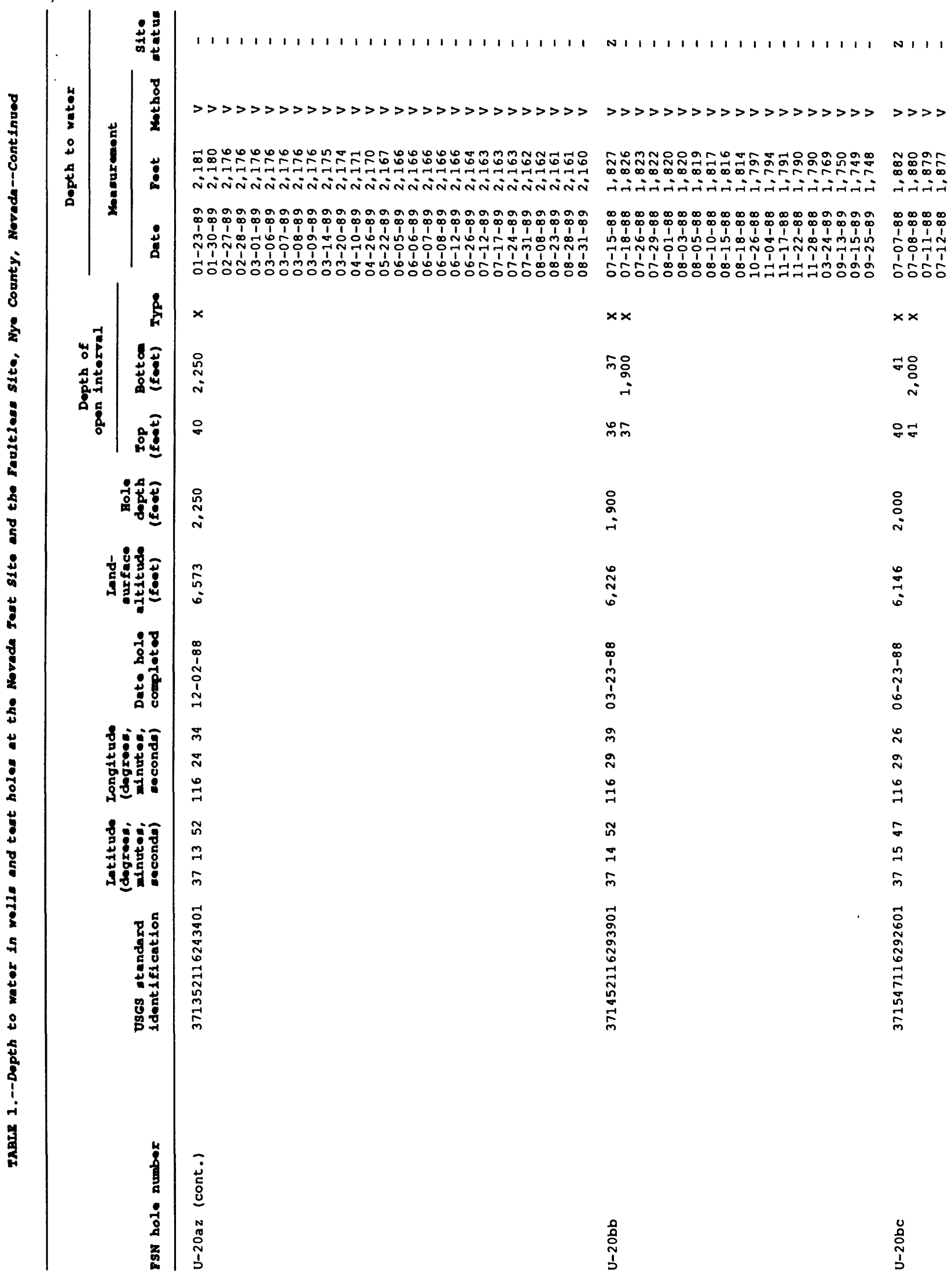




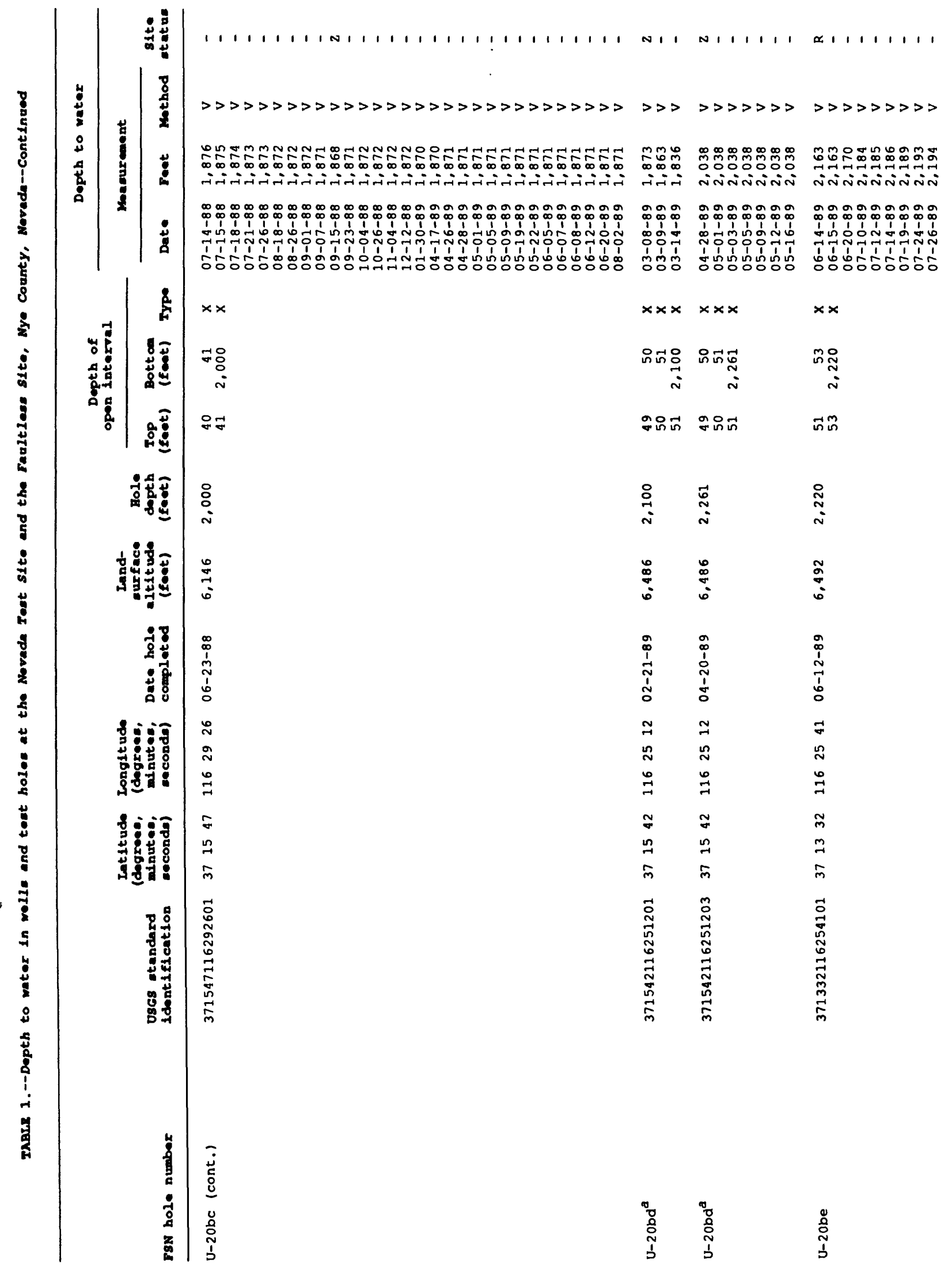




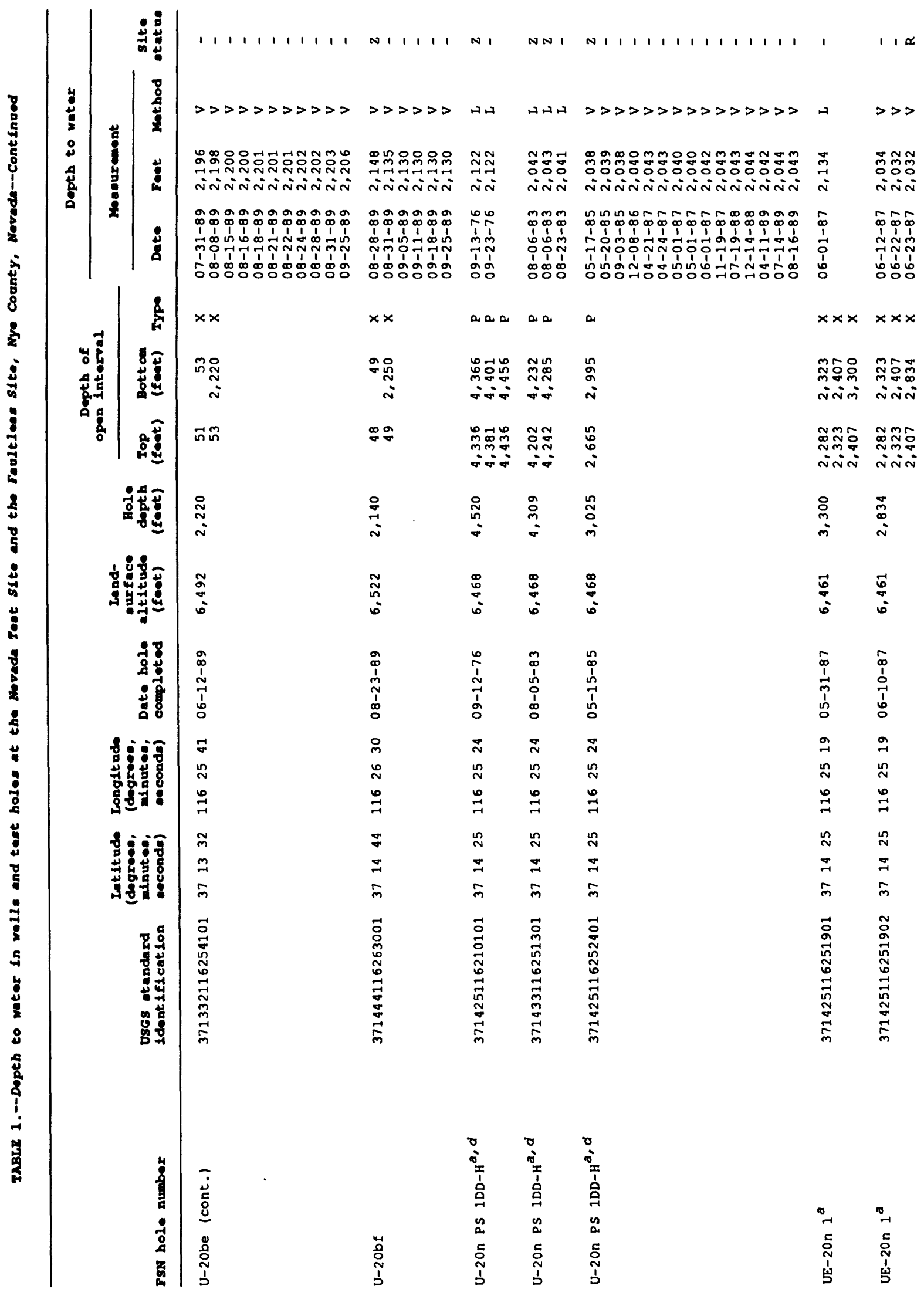




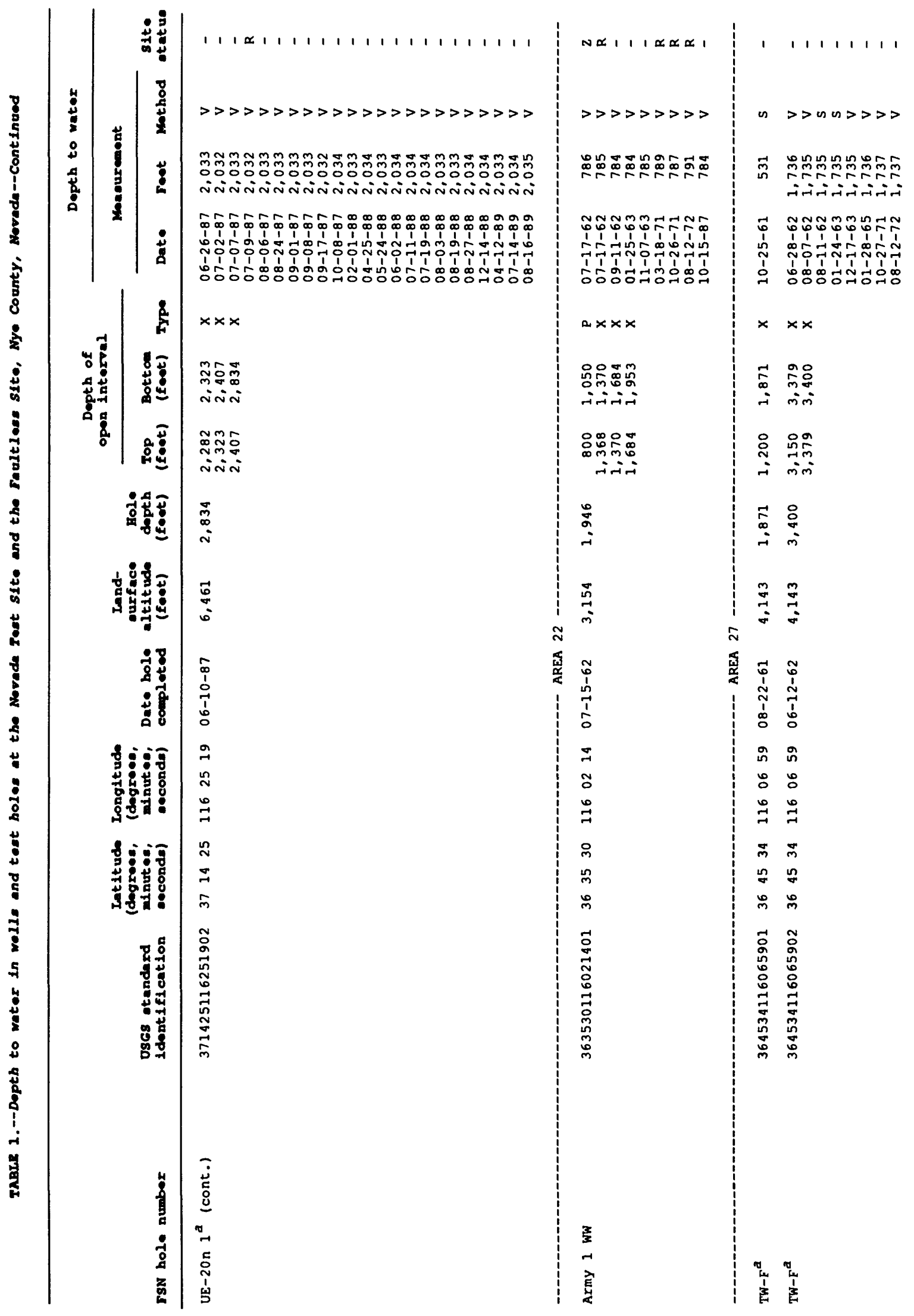




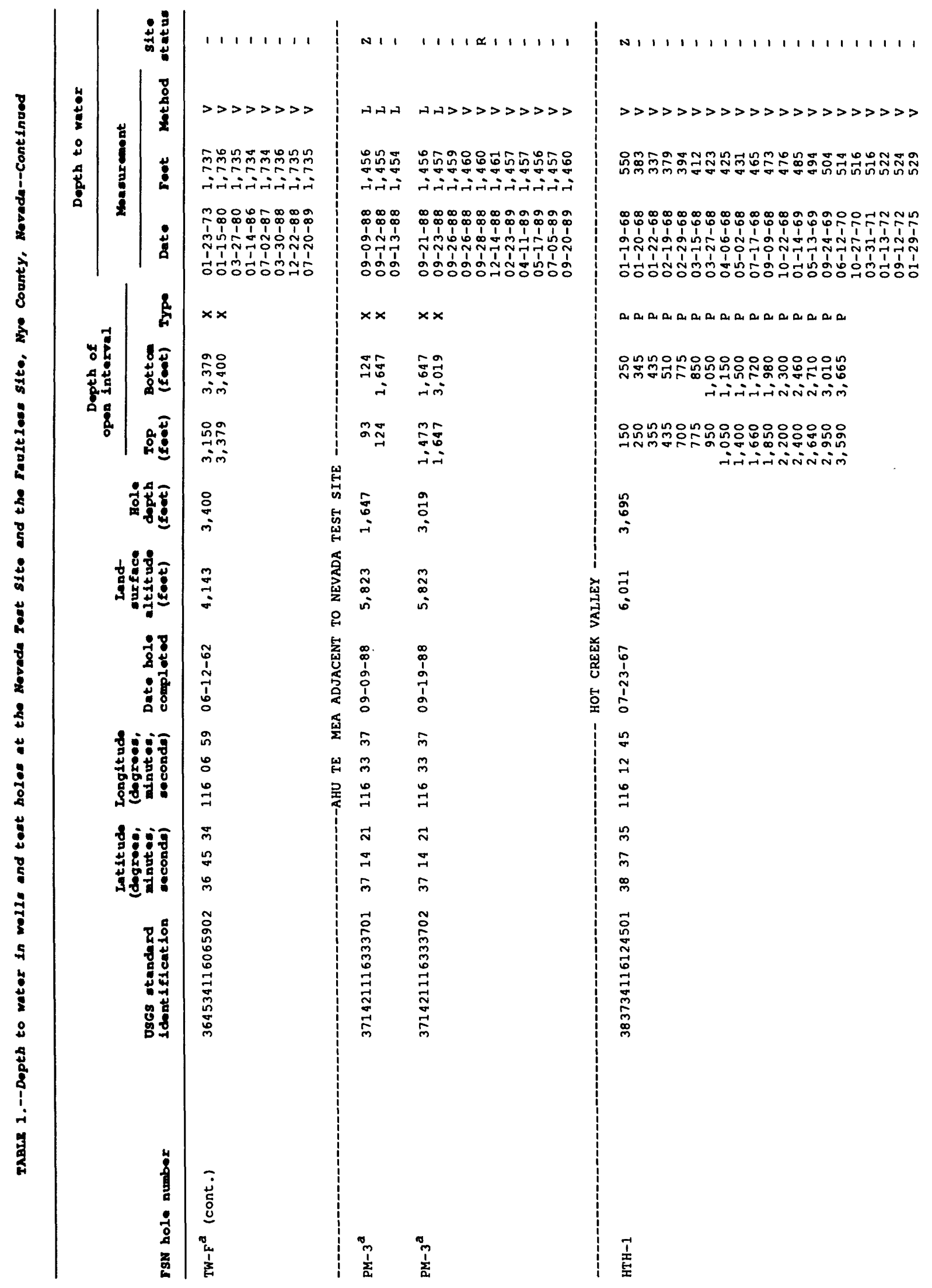




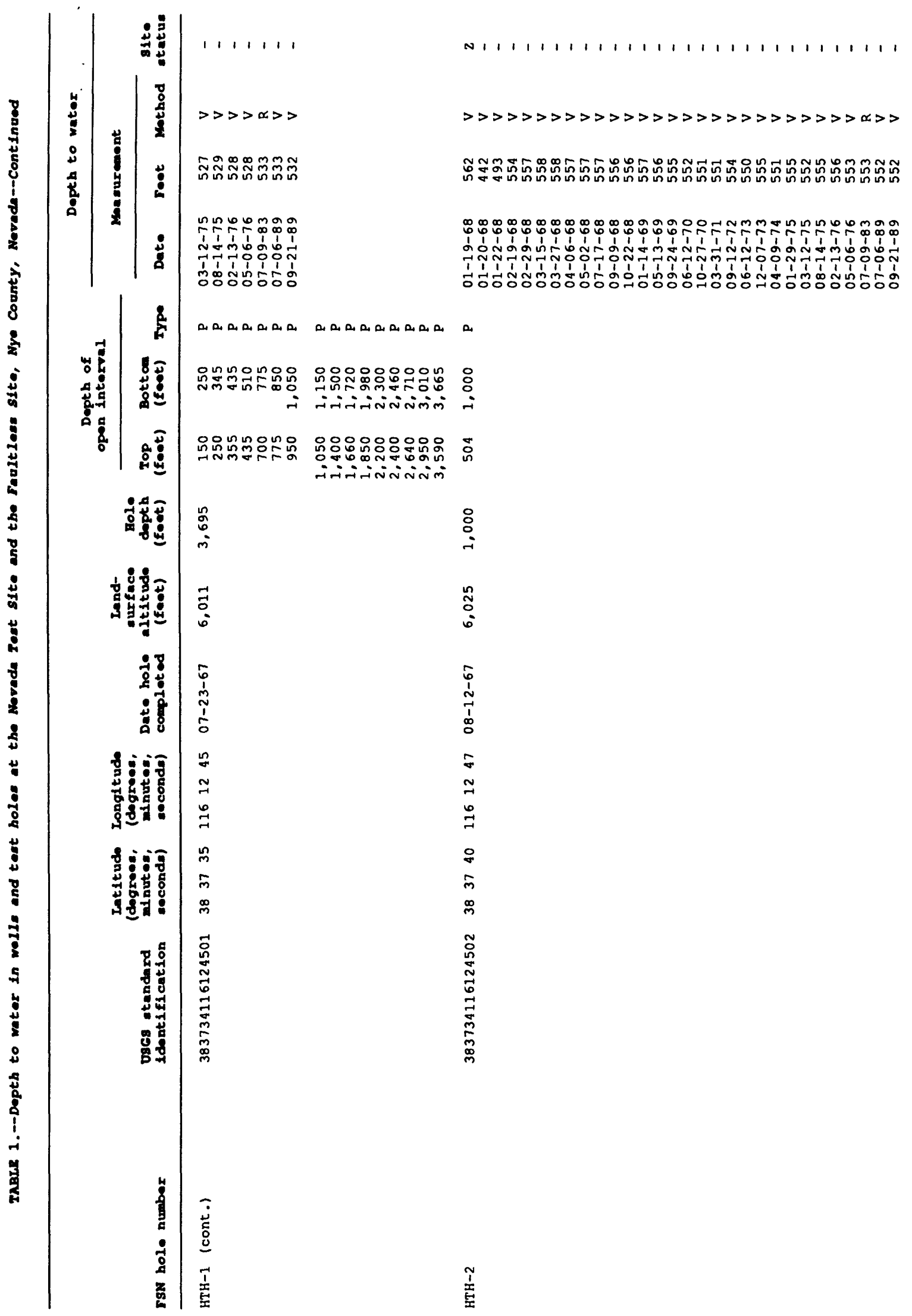




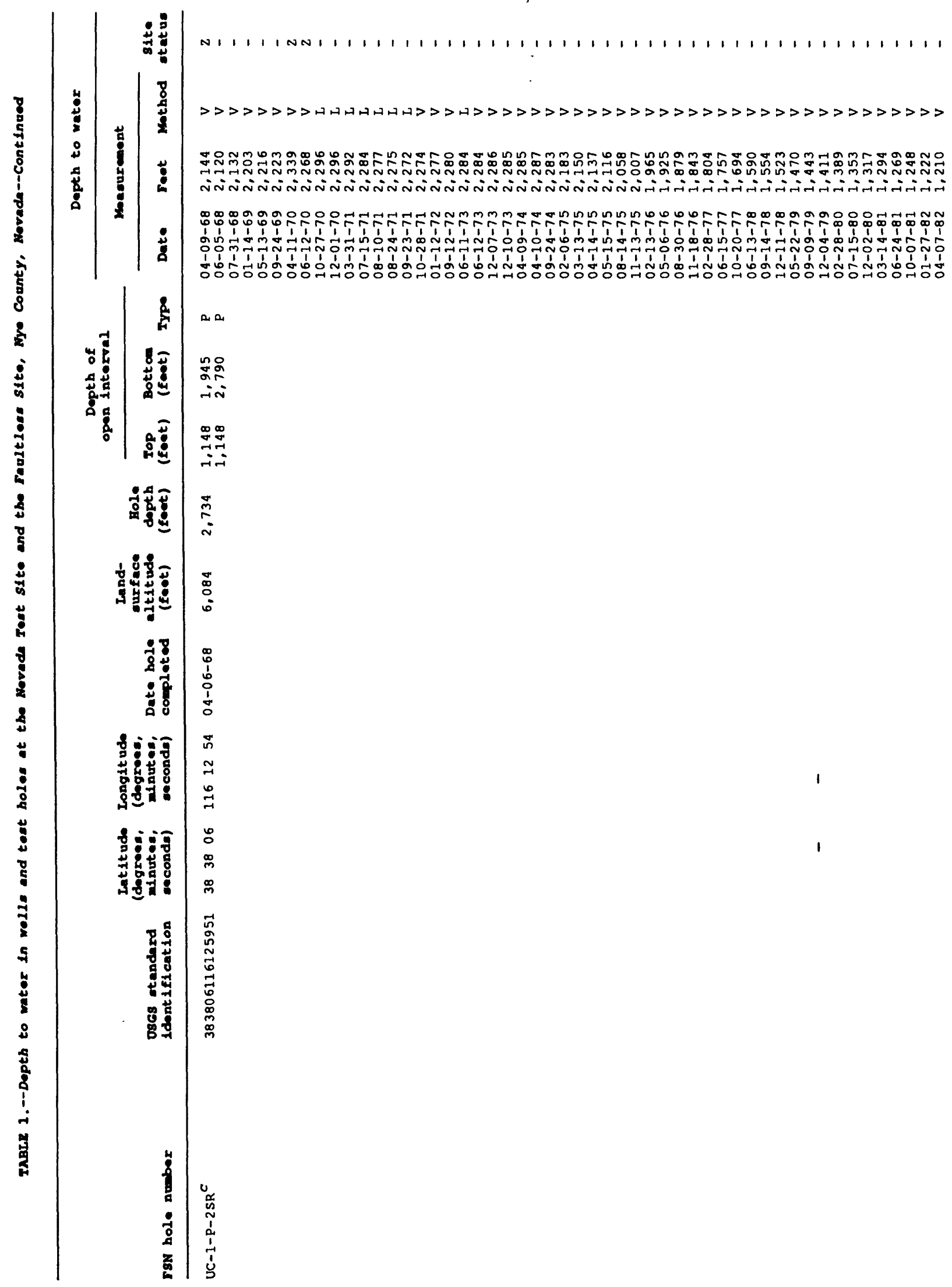




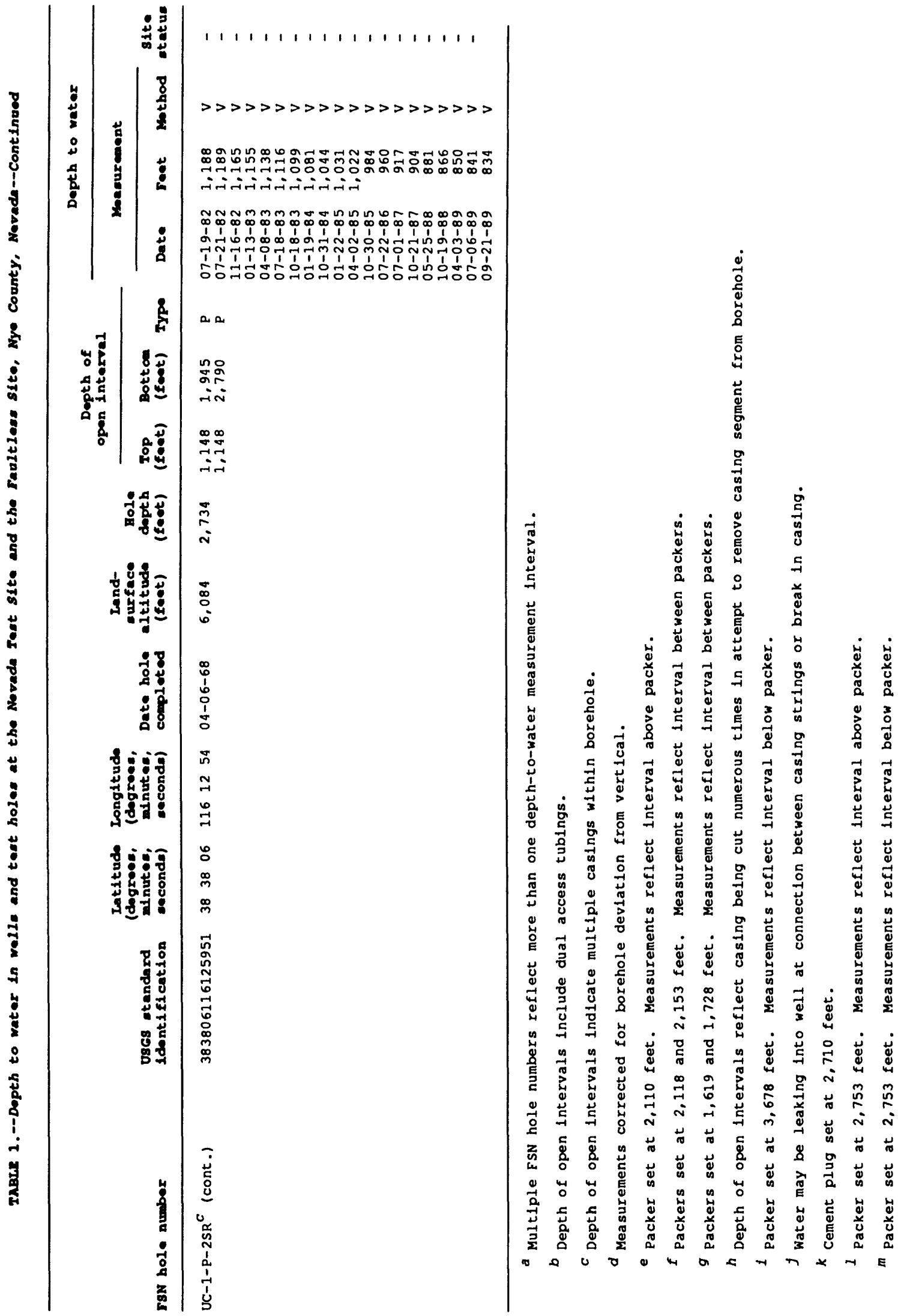




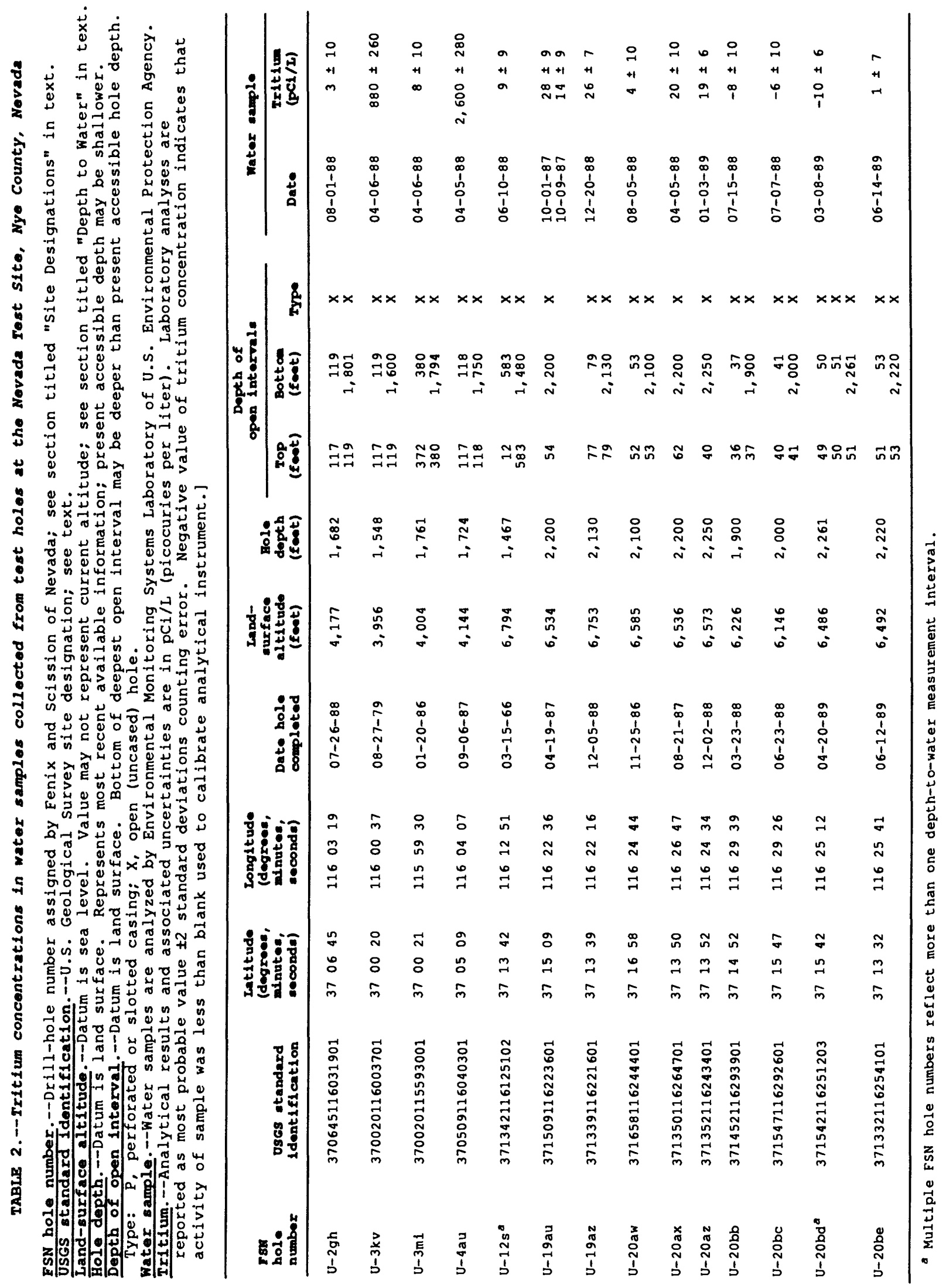

